\title{
Integrated biostratigraphy and carbon isotope stratigraphy of the Upper Jurassic shallow water carbonates of the High-Tatric Unit (Mały Giewont area, Western Tatra Mountains, Poland)
}

\author{
Andrzej PSZCZÓŁKOWSKI ${ }^{1}$, Jacek GRABOWSKI ${ }^{2},{ }^{*}$ and Andrzej WILAMOWSKI ${ }^{2}$ \\ 1 Polish Academy of Sciences, Institute of Geological Sciences, Twarda 51/55, 00-818 Warszawa, Poland \\ 2 Polish Geological Institute - National Research Institute, Rakowiecka 4, 00-975 Warszawa, Poland
}

Pszczółkowski, A, Grabowski, J., Wilamowski, A., 2016. Integrated biostratigraphy and carbon isotope stratigraphy of the Upper Jurassic shallow water carbonates of the High-Tatric Unit (Mały Giewont area, Western Tatra Mountains, Poland). Geological Quarterly, 60 (4): 893-918, doi: 10.7306/gq.1333

\begin{abstract}
New biostratigraphical and carbon isotope data are presented for the Upper Jurassic limestones of the Raptawicka Turnia Limestone Formation (High-Tatric Unit, Western Tatra Mountains, Poland) from the Mały Giewont area. The Kimmeridgian, Lower Tithonian and lower part of the Upper Tithonian have been identified on the basis of calcareous dinocysts and calpionellids. Eight microfossil biozones are distinguished: acme Fibrata, acme Parvula, Moluccana, Borzai, Tithonica-acme Pulla(?), Malmica, Chitinoidella and Crassicollaria (pars). The Kimmeridgian/Tithonian boundary is inferred at the top of the Borzai Zone, $76 \mathrm{~m}$ above the base of the Raptawicka Turnia Limestone Formation. The microfossil stratigraphy suggests a late Early Kimmeridgian age (acme Parvula Zone) for the ammonites described by Passendorfer (1928). The taxon Taramelliceras ex gr. compsum found $14 \mathrm{~m}$ above those ammonites is Late Kimmeridgian in age. Seven microfacies types (MF) are identified in the Upper Jurassic limestones of the Mały Giewont area. The Bositra-Saccocomidae MF occurs across the Lower-Upper Kimmeridgian boundary. The presence of planktonic and benthic foraminifers was documented in the Upper Jurassic deposits of the Raptawicka Turnia Limestone Formation. The genera Lenticulina Lamarck and Spirillina Ehrenberg are common in the Kimmeridgian and Tithonian limestones. The palaeobathymetric evolution of the Kimmeridgian-Tithonian deposition recorded in the Mały Giewont sections reveals: a transgressive episode at the Early/Late Kimmeridgian boundary interval, a transgression peak in the Early Tithonian (Malmica Zone) and gradual shallowing of the High-Tatric swell in the Late Tithonian. Integrated isotope stratigraphy and biostratigraphy enabled correlation with the pelagic section of the Sub-Tatric Succession in the Długa Valley section. The middle part of the Raptawicka Turnia Limestone Formation (Upper Kimmeridgian) may be correlated with the upper part of the Czajakowa Radiolarite Formation (red radiolarites) and Czorsztyn Limestone Formation in the Długa Valley (Western Tatra Mts.) section. The upper part of the Raptawicka Turnia Limestone Formation (Lower Tithonian) corresponds mostly to the Jasenina Formation. The overall similarity of the $\delta^{13} \mathrm{C}$ decreasing values recorded in the Kimmeridgian-earliest Tithonian interval of the Mały Giewont (this study) and Długa Valley sections indicates that the generally shallow-water deposits of the Raptawicka Turnia Limestone Formation accumulated below the zone that was influenced by changes in the composition of marine water caused, for instance, by intense rainfall.
\end{abstract}

Key words: biostratigraphy, carbon isotope stratigraphy, Raptawicka Turnia Limestone Formation, High-Tatric Succession, Tatra Mts.

\section{INTRODUCTION}

The Late Jurassic epoch in the Central Western Carpathians is regarded as a period of maximum palaeobathymetric and palaeofacies differentiation (Vašiček et al., 1994). During the Late Tithonian, the Tatric Ridge occupied a marginal (northern) position on the Alpine-Carpathian microcontinent (Vašiček et al., 1994: text-fig. 3; Michalík, 2007). The High-Tatric Succession of the Western Tatra Mountains belongs to the South Tatric Ridge in the palaeogeographical scheme proposed by Plašienka

* Corresponding author, e-mail: jacek.grabowski@pgi.gov.pl

Received: October 18, 2016; accepted: November 24, 2016; first published online: December 20, 2016
(1995: fig. 9). According to Lefeld (1985 in Lefeld et al., 1985: p. 10-11), the facies of the High-Tatric Succession in the Western Tatra Mountains are predominantly of geanticlinal character and the Upper Jurassic strata of the Raptawicka Turnia Limestone Formation (RTL Fm) “....represent open-oceanic, though not necessarily deep, depositional conditions...". However, a detailed stratigraphical subdivision of the Upper Jurassic limestones of the RTL Fm was not achieved at that time, probably because of the scarcity of macrofauna and index microfossils.

The main objective of this study is to develop a biostratigraphical scheme of the Upper Jurassic shallow-water limestones exposed on the western slopes of Mały Giewont by means of microfossils and to compare the results with the carbon isotope record for the Kimmeridgian-Tithonian interval. Our results can also be correlated with the earlier published data for the West Carpathian sections, mainly for the Sub-Tatric Succession (Krížna) in the Western Tatra Mountains (Jach et al., 2014). 


\section{GEOLOGICAL SETTING AND PREVIOUS STUDIES}

The thick-bedded to massive Upper Jurassic limestones of the High-Tatric Succession are exposed on the western slope of the Mały Giewont Mount (Fig. 1). These limestones belong to the RTL Fm of Callovian through Hauterivian age (Lefeld, 1985 in Lefeld et al., 1985: p. 25-34). Much earlier, Passendorfer (1928), on the basis of ammonites, documented the Kimmeridgian age of grey limestones exposed on the Mały Giewont (western) mountainside. Kotański and Radwański (1960) identified "Lombardia microfacies" (= Saccocoma microfacies) and found one specimen of Calpionella alpina in the limestones located above the strata that yielded Kimmeridgian ammonites. Lefeld and Radwański (1960) described the occurrence of Saccocoma Agassiz in the Upper Jurassic and Lower Cretaceous limestones of the High-Tatric Succession, also in the Mały Giewont section. The authors concluded that the "pseudo-ooids", very common in these limestones, were formed probably as a result of the activity of Cyanophyceae.

According to Lefeld (1985 in Lefeld et al., 1985: p. 25-34), the limestones of the RTL Fm are subdivided into three informal members: lower (pinkish, locally greenish Callovian-Oxfordian limestones), middle (light grey Upper Oxfordian-Berriasian limestones) and upper represented by dark brown, almost black oncolitic limestones that are Valanginian-Hauterivian in age. A few poorly preserved calpionellids have been found in the limestones correlated with the Tithonian-Berriasian (undivided); however, these microfossils were not located on the generalized lithostratigraphic column (Lefeld, 1968: fig. 10).

Borowska (2015) studied the stratigraphy of the Tithonian-Aptian limestones exposed in the Niedźwiedź crag located about $1.4 \mathrm{~km}$ west of the Mały Giewont sections (Fig. 1B). In the Niedźwiedź section, Lower to Middle Tithonian limestones with Parastomiosphaera malmica (Borza) and Haghimashella arcuata (Haeusler) $86 \mathrm{~m}$ thick, as well as the Berriasian-Valanginian limestones (about $118 \mathrm{~m}$ thick), have been reported (Borowska, 2015: fig. 6).

\section{MATERIALS AND METHODS}

One of the reference sections of the Raptawicka Turnia Limestone Formation was designated on the western slope of the Mały Giewont Mount (Lefeld, 1985 in Lefeld et al., 1985: p. 26). Two sections were studied on this mountainside: $(A)$ on the upper part of the slope and $(B)$ about $55 \mathrm{~m}$ west of the former one (Fig. 1B and C, 2 and 3). Furthermore, a few samples were collected from the lower part of the RTL Fm, along the tourist track leading to Giewont Mount $(P$ in Fig. 1C). The stratigraphical location of these samples is shown in the lowermost part of the section $B(P-626$ to $\mathrm{P}-642$ in Fig. 3). Sampling of section A took place in July 2013 (64 samples, between MG-56 and MG-120) while fieldwork on sections $B$ and $P$ was carried out in 1989-1990. Sixty-nine samples (G-1 to G-69) were collected from section $B$ and 17 samples from section
$\mathrm{P}$ (P-626 to P-642). Section B is currently heavily overgrown by vegetation. Some parts of section $A$ are also not accessible for observation due to grass cover (Appendix $1^{*}$ ).
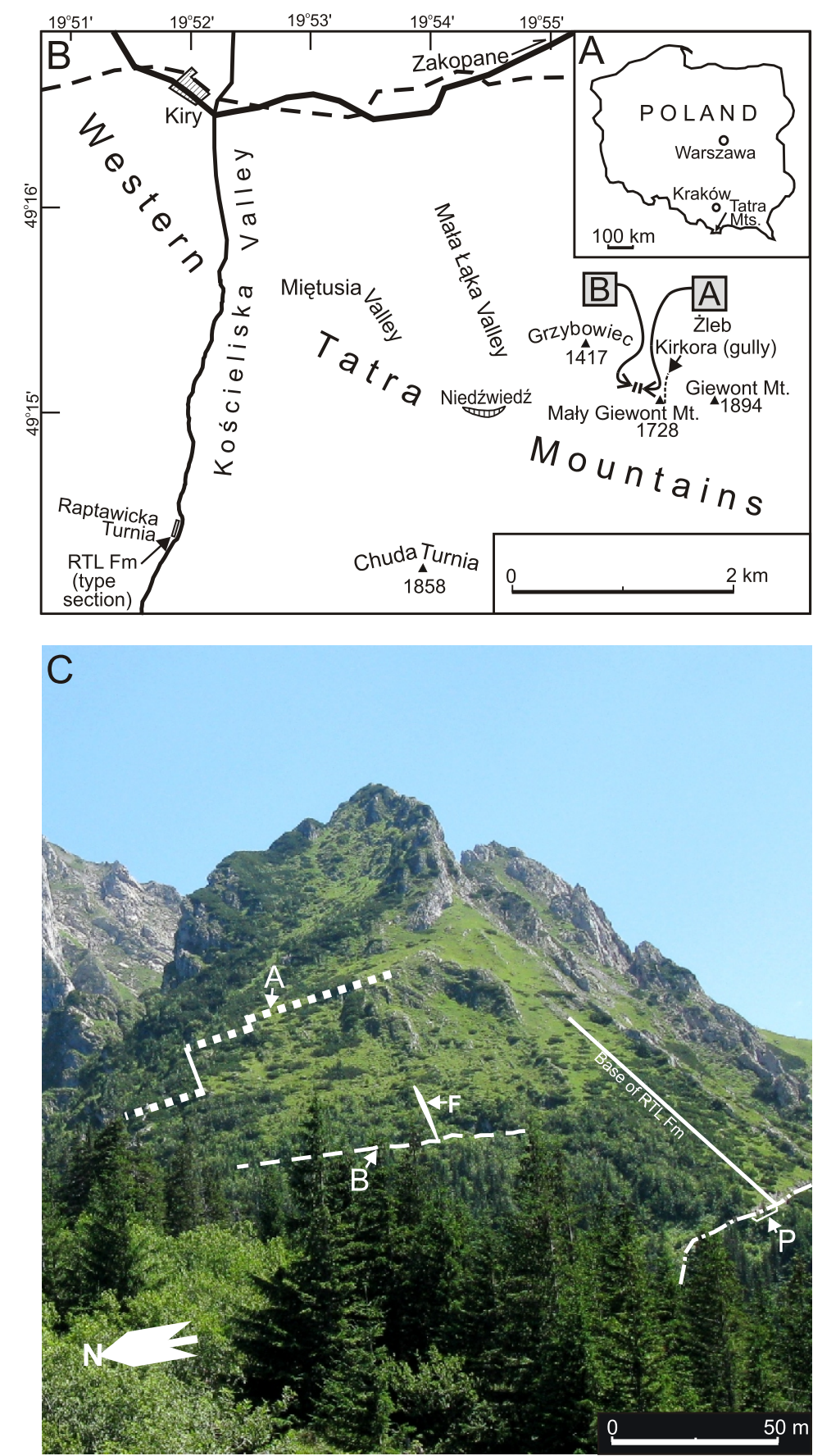

Fig. 1A - location of the Tatra Mts. in southern Poland; B - general location of the studied sections of the Raptawicka Turnia Limestone Formation (A, B) on the western slope of Mały Giewont Mount, Western Tatra Mts.; the type section of this formation in the Kościeliska Valley is also indicated (RTL Fm, after Lefeld, 1985 in Lefeld et al., 1985); C - detailed location of the studied sections (A, B) on the western slope of the Mały Giewont Mount

$\mathrm{F}$ - limestone beds that yielded the Kimmeridgian ammonites (Passendorfer 1928), cf. site a in the section B, Figure 3; P - location of the samples P-626 to P-642 collected along the tourist trail leading to Giewont Mount (see Fig. 3) 


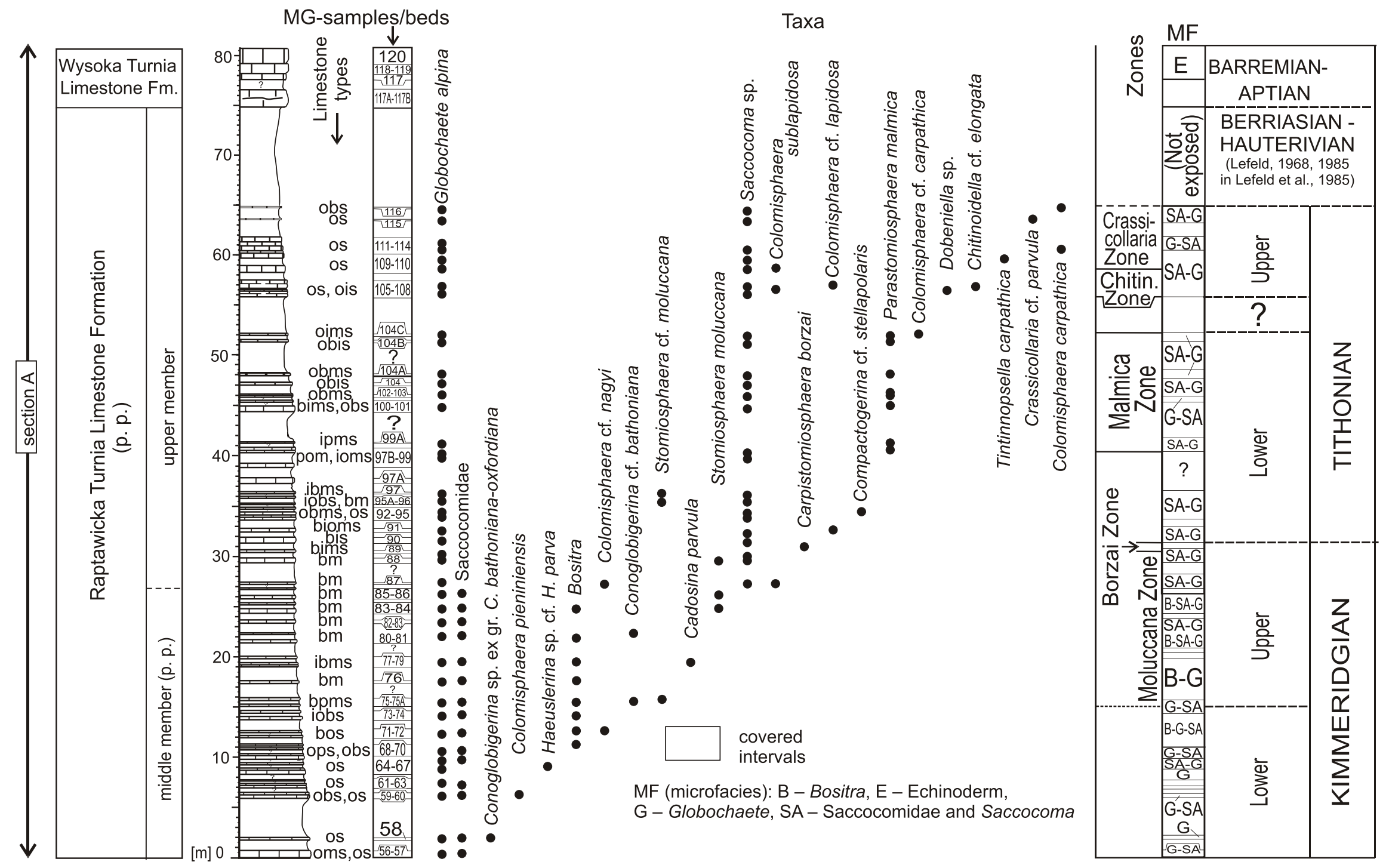

Fig. 2. Lithology, sampling, microfacies and biostratigraphy of section $A$

(western slope of Mały Giewont Mount in the Western Tatra Mountains, see Fig. 1B, C)

bims - biointramicrosparite, bioms - biointraoncomicrosparite, bis - biointrasparite, bm - biomicrite, bos - biooncosparite, bpms - biopelmicrosparite, iobs - intraoncobiosparite, ibms intrabiomicrosparite, ioms - intraoncomicrosparite, ipms - intrapelmicrosparite, obis - oncobiointrasparite, obms - oncobiomicrosparite, obs - oncobiosparite, oims - oncointramicrosparite,

ois - oncointrasparite, oms - oncomicrosparite, ops - oncopelsparite, os - oncosparite, pom - peloncomicrite (based on classification of Folk, 1959); Chitin. - Chitinoidella 


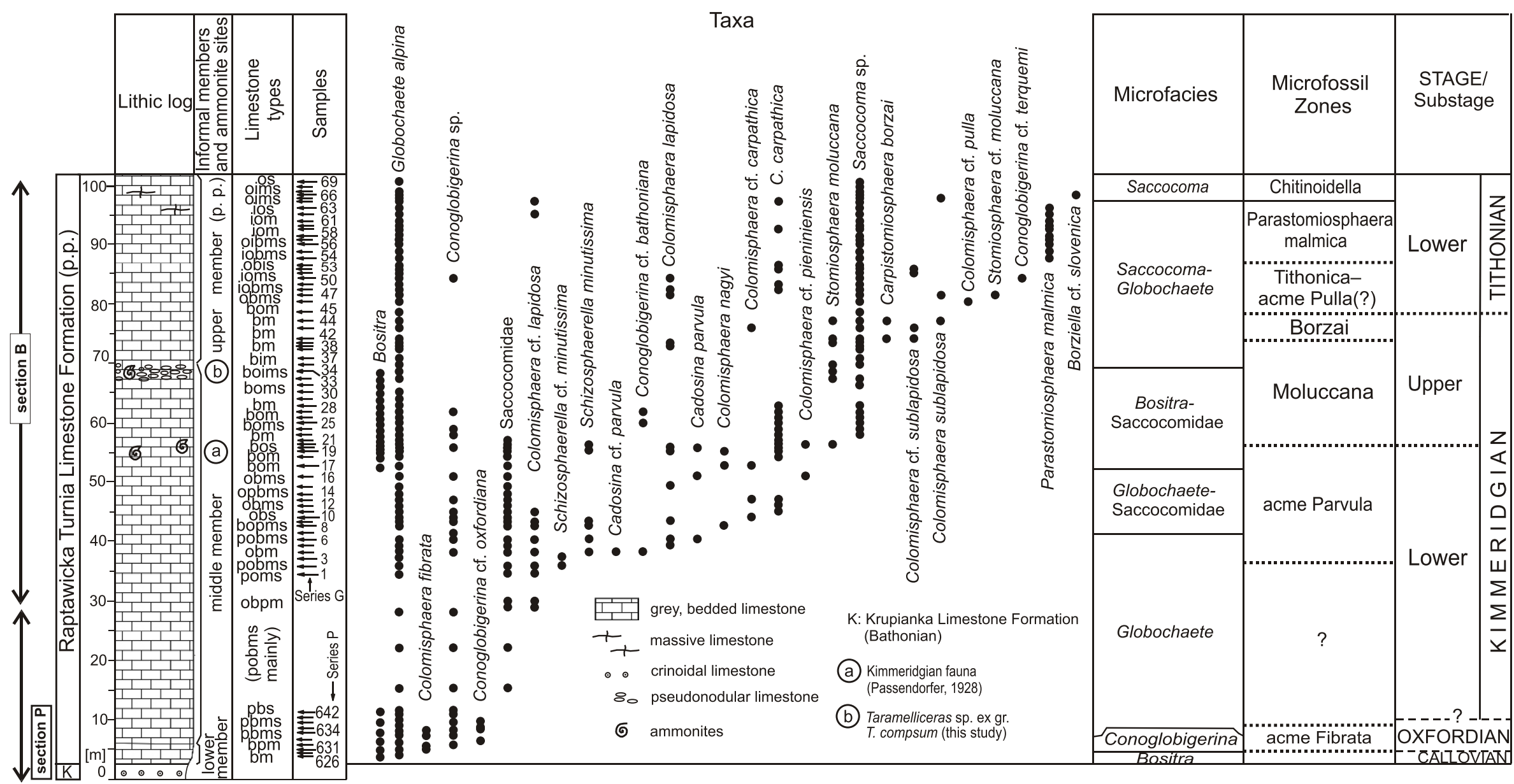

Fig. 3. Lithology, sampling, microfacies and biostratigraphy of section $B$ and $P$

(western slope of Mały Giewont Mount in the Western Tatra Mountains, see Fig. 1B, C)

boims - biooncointramicrosparite, bom - biooncomicrite, boms - biooncomicrosparite, bpm - biopelmicrite, iobms - intraoncobiomicrosparite, iom - intraoncomicrite, ios - intraoncosparite, obm - oncobiomicrite, obpm - oncobiopelmicrite, oibms - oncointabiomicrosparite, opbms - oncopelbiomicrosparite, pbms - pelbiomicrosparite, pbs - pelbiosparite, pobms - peloncobiomicrosparite, poms - peloncomicrosparite, for other explanations see Figure 2 
Thin-sections for biostratigraphical investigations were prepared at the Institute of Geological Sciences, Polish Academy of Sciences, Research Centre in Warsaw (sections P and B) and in the Polish Geological Institute - National Research Institute (section A). Scanning photomicrographs were taken at the Institute of Geological Sciences, Polish Academy of Sciences, Warsaw Research Centre.

Stable isotope analyses were performed on 40 bulk rock samples. Powdered bulk-carbonate samples were reacted with $100 \% \mathrm{H}_{3} \mathrm{PO}_{4}$ at $70^{\circ} \mathrm{C}$ in an online, automated carbonate reaction device (Kiel IV) connected to a Finnigan Mat Delta Plus mass spectrometer at the Institute of Geological Sciences, Polish Academy of Sciences in Warsaw. Isotopic values are reported in per mile relative to the VPDB scale and referenced to the values of NBS19 standard $\left(\delta^{13} \mathrm{C}=1.95 \%, \delta^{18} \mathrm{O}=-2.20 \%\right.$ ). The reproducibility and accuracy of the measurements was monitored, by replicate analysis of NBS19 standard $(n=235)$. Reproducibility for $\delta^{13} \mathrm{C}$ and $\delta^{18} \mathrm{O}$ values was $0.032 \%$ and $0.086 \%$ o $( \pm 1 \sigma)$, respectively.

\section{RESULTS}

\section{BIOSTRATIGRAPHY}

Biostratigraphical subdivision of the RTL Fm exposed on the western slope of the Mały Giewont Mount (Fig. 1C) is based on the planktonic microfossils, mainly calcareous dinoflagellate cysts and calpionellids, because macrofauna is scarce in these Upper Jurassic limestones. However, the index planktonic microfossils are also uncommon in the shallow-water Kimmeridgian and Tithonian limestones studied (Lefeld, 1968). The subdivision of the Upper Oxfordian-Tithonian interval based on saccocomid skeletal sections proposed by Benzaggagh et al. (2015) for the western Tethyan realm, although interesting, has been correlated with the ammonite zones, only.

\section{MICROFOSSIL ZONES}

In the Mały Giewont sections, the following zones based on calcareous dinoflagellate cysts (Reháková, 2000a, b; Jach et al., 2014) are distinguished in the limestones of the RTL Fm studied: acme Fibrata (after Jach et al., 2014), acme Parvula, Moluccana, Borzai, Tithonica-acme Pulla(?) and Malmica (Figs. 2-4).

The acme Fibrata Zone: although the Oxfordian-lowermost Kimmeridgian limestones were not investigated in detail, Colomisphaera fibrata (Nagy) was found (Fig. 5A) in a few samples taken along the tourist trail, $2.5-4.5 \mathrm{~m}$ above the base of the Raptawicka Turnia Limestone Formation (Figs. 1C and 3, samples P-631 to P-634).

Between the acme Fibrata Zone and the next identified biozone (acme Parvula Zone) there are limestones $\sim 29 \mathrm{~m}$ thick, which did not yield index calcareous dinoflagellate cysts (Fig. 3). Those Upper Oxfordian-Lower Kimmeridgian limestones contain relatively frequent foraminifera (Conoglobigerina sp., Lenticulina spp., Spirillina sp., Nodosariidae). Colomisphaera cf. lapidosa (Vogler) occurs in the uppermost part of the limestones. Microoncoids and peloids are common, with microbial filaments and (occasionally) calcareous nannofossils inside.

The acme Parvula Zone is recognized in section $B$, only (Fig. 3, samples G-3 to G-20). The following taxa occur in these samples: Cadosina parvula Nagy (Fig. 6A), Cd. cf. parvula
Nagy, Colomisphaera lapidosa (Vogler) (Fig. 6B), C. cf. lapidosa (Vogler), C. nagyi (Borza) (Fig. 6C, D) and C. pieniniensis (Borza). The taxon C. pieniniensis was found also in section $A$ (Fig. 7A, sample MG-59), in the interval located below the Moluccana Zone, probably corresponding to the acme Parvula Zone, although the nominal index species was not identified (Fig. 2).

Sample G-19 was collected from the uppermost part of the acme Parvula Zone (Fig. 3); this limestone bed probably yielded the Kimmeridgian ammonites found by Passendorfer (1928). The limestone is oncobiosparite with minor amount of small peloids, which contain thin microbial filaments (Fig. 5B). The following microfossils were identified in the thin-section G-19:

Colomisphaera nagyi (Borza) (Fig. 6D)

C. carpathica (Borza)

C. lapidosa (Vogler) (Fig. 6B)

Schizosphaerella minutissima(?) (Colom)

The presence of Colomisphaera nagyi (Borza) indicates the Late Kimmeridgian age of this sample (Borza, 1969, 1984; Reháková, 2000a). However, Reháková et al. (2011) have shown that the taxon $C$. nagyi (Borza) occurs from the uppermost Oxfordian to the lowermost Tithonian in the Veliky Kamenets section (Carpathians, Western Ukraine). It seems that the earlier opinion concerning an exclusively Late Kimmeridgian age of C. nagyi (Borza, 1984; Reháková, 2000a, b) is no more valid. Ivanova and Keupp (1999) included this taxon in Pirumella thayeri (Bolli) Lentin and Williams (subfamily Obliquipithonelloideae Keupp, 1987). Recently, the acme Parvula Zone was correlated with the upper part of the Lower Kimmeridgian in the Western Tatra sections of the Sub-Tatric Succession (Jach et al., 2014: fig. 17).

The Moluccana Zone is distinguished in both studied sections A and B (Figs. 2-4). The occurrence of Stomiosphaera moluccana Wanner (Fig. 7C) was recorded in the samples collected from both sections studied (Figs. 2 and 3), but Colomisphaera sublapidosa (Vogler) (Fig. 7B) was found in the section $\mathrm{A}$, only. In these sections the Moluccana Zone comprises limestones 15 and $17.5 \mathrm{~m}$ thick, respectively. Ivanova and Keupp (1999) included St. moluccana Wanner in the taxon Orthopithonella gustafsonii (Bolli) Lentin and Williams. The Moluccana Zone is Late Kimmeridgian in age (Nowak, 1968; Borza, 1984; Reháková, 2000a; Jach et al., 2014).

The Borzai Zone (uppermost Kimmeridgian) is represented by one limestone bed with Carpistomiosphaera borzai (Nagy) (Fig. 7F) in section A (Fig. 2, sample MG-89). In section $\mathrm{B}$, however, this zone comprises limestones $4.5 \mathrm{~m}$ thick. The following taxa were identified in the thin-section G-44: Carpistomiosphaera borzai (Nagy) (Fig. 7E), Colomisphaera sublapidosa (Vogler) and Stomiosphaera moluccana Wanner (Fig. 7D). Ivanova and Keupp (1999) included the taxon C. borzai in the species Pirumella piriformis (Keupp) Lentin and Williams. The Borzai Zone was correlated with the upper part of the ammonite Beckeri Zone (Řehánek and Cecca, 1993).

The Tithonica-acme Pulla(?) Zone is tentatively distinguished in section B only (Figs. 3 and 4); this zone comprises Lower Tithonian limestones $9 \mathrm{~m}$ thick. However, the thickness of this compound zone was estimated based mainly on the position of the strata occurring between the Borzai and Malmica zones. The following taxa were recognized in these limestones: Colomisphaera cf. pulla (Borza) (Fig. 8A), Colomisphaera lapidosa (Vogler, 1941), C. sublapidosa (Vogler) (Fig. 8B), Stomiosphaera cf. moluccana Wanner, 1940 and Colomisphaera carpathica (Borza) (Fig. 8C).

The Malmica Zone (Lower Tithonian) is documented in both sections studied (Figs. 2 and 3 ). This zone comprises lime- 


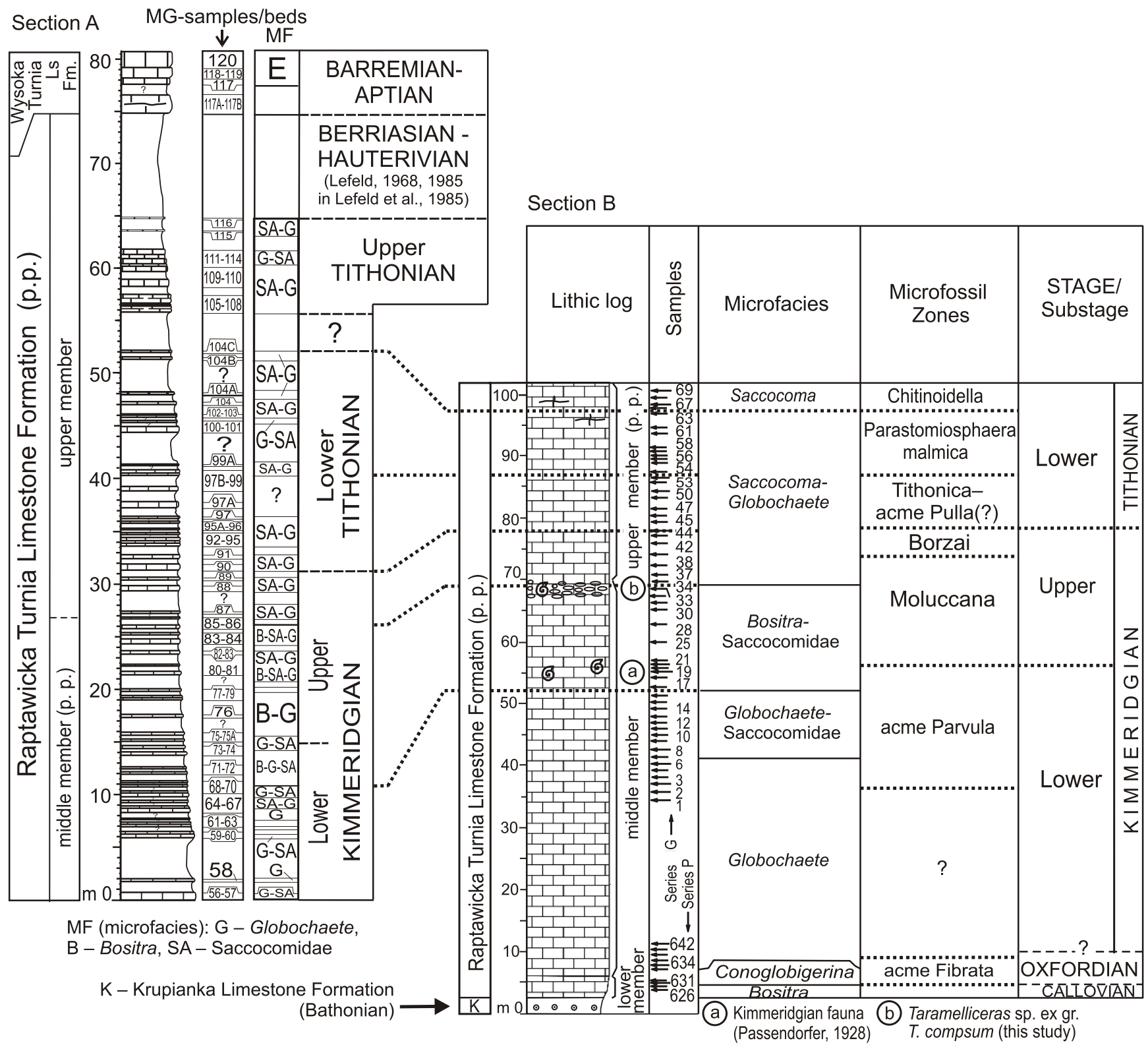

Fig. 4. Correlation of the three sections (A, B and P; Fig. 1C) located on the western slope of Mały Giewont Mount in the Western Tatra Mountains

For other explanations see Figures 2 and 3

stones $12 \mathrm{~m}$ thick in section $\mathrm{A}$, and $11 \mathrm{~m}$ thick in section $\mathrm{B}$. The index taxon - Parastomiosphaera malmica (Figs. 8D, E and $9 \mathrm{~A}-\mathrm{C})$ - is common in both sections. In the thin-section G-56 (section B, Fig. 3), a specimen of Nannoconus globulus minor Bralower, 1989 (Fig. 8E, F) was found inside the test of Parastomiosphaera malmica (Borza). The specimen's dimensions are as follows: width $6.8 \mu \mathrm{m}$ and height $5.3 \mu \mathrm{m}$. As sample G-56 was taken from the lower part of the Lower Tithonian Malmica Zone, the presence of $N$. globulus minor changes the known stratigraphical range of this nannofossil. According to Bralower et al. (1989), N. globulus minor appeared in the Upper Tithonian (M19n magnetozone). Michalík et al. (2009) have shown the first occurrence (FO) of this taxon in the $\mathrm{M} 18 \mathrm{r}$ magnetozone (bed C27E, above their $\mathrm{J} / \mathrm{K}$ boundary). Casellato (2010: fig. 16) indicated the FO of $N$. globulus minor in the Upper Tithonian (uppermost interval of the M20n magnetozone).
Earlier, however, N. globulus minor was reported from the Boneti Subzone in the Kryta Valley of the Sub-Tatric Succession of the Western Tatra Mountains (Pszczółkowski, 2009), within the lower interval of the M20n magnetozone (Grabowski and Pszczółkowski, 2006). In the Brodno section (Pieniny Klippen Belt, Slovakia), the Malmica Zone corresponds to the M21r and M21n (lower interval) magnetozones (Michalík et al., 2009).

The Chitinoidella Zone (Lower/Upper Tithonian) is recognized in both sections (Figs. 2 and 3 ). In section $A$, this zone (pars) comprises limestones about $1.5 \mathrm{~m}$ thick, but they are nearly $4.5 \mathrm{~m}$ in section B (Fig. 3). The specimens of Chitinoidellidae are scarce and poorly preserved (Fig. 9D-F). Moreover, Colomisphaera sublapidosa (Vogler) occurs in the Chitinoidella Zone. 

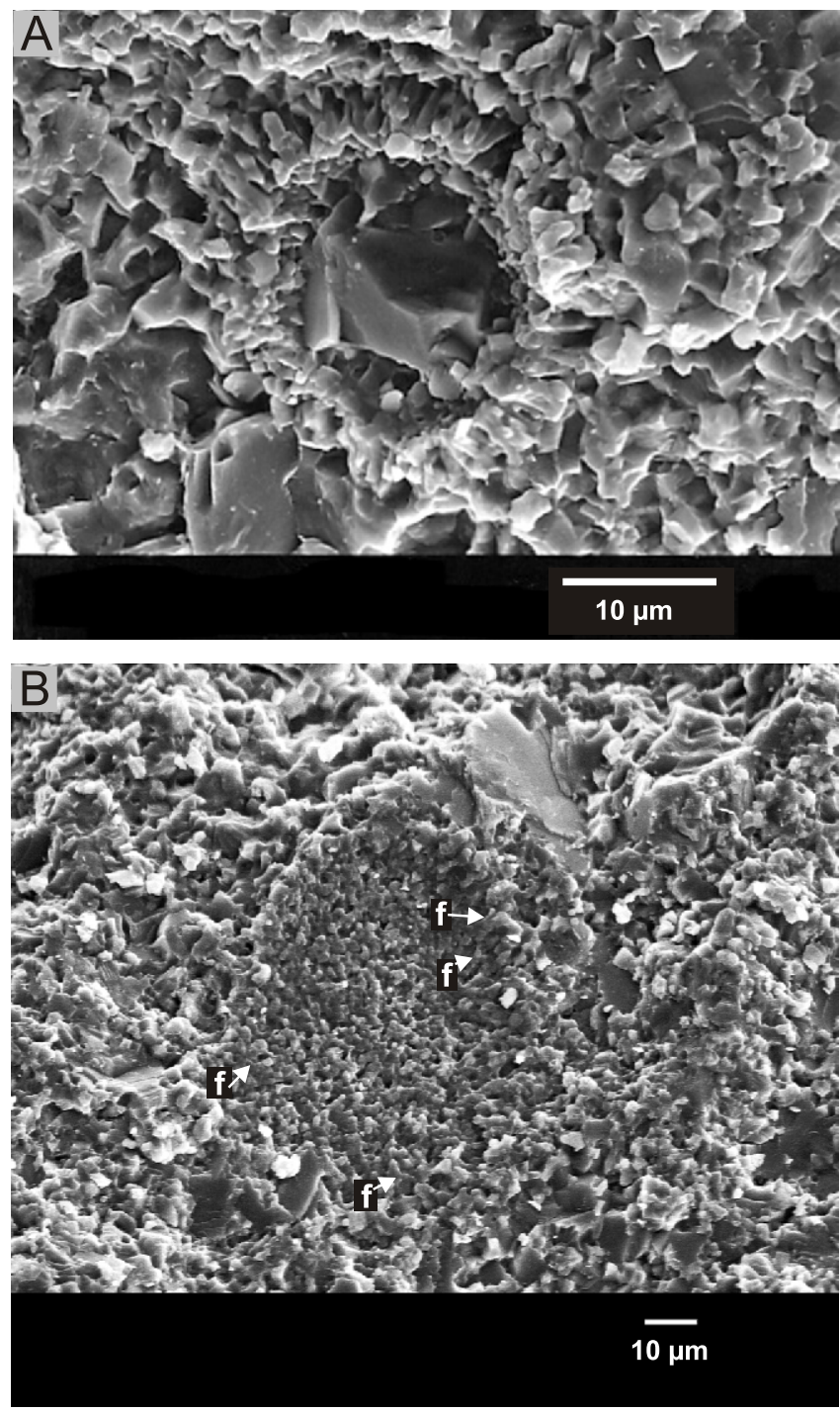

Fig. 5A - SEM photomicrograph of Colomisphaera fibrata (Nagy), Oxfordian, sample P-631 (shown in section B, Fig. 3); B - SEM photomicrograph of a small peloid $(80 \times 67 \mu \mathrm{m}$ in cross-section), which contains a few thin microbial filaments (f); thin-section G-19, section B (Fig. 3), Lower Kimmeridgian

The Crassicollaria Zone (Upper Tithonian), recognized in section A only, is composed of limestones $\sim 5 \mathrm{~m}$ thick (Fig. 2 ). The calpionellids are very scarce and poorly preserved, usually occurring inside the microoncoids (Fig. 10A). Only two taxa could be identified: Tintinnopsella carpathica (Murgeanu and Filipescu) (Fig. 10B) and Crassicollaria cf. parvula Remane (Fig. 10C). Colomisphaera carpathica (Borza) occurs in the thin-section MG-116, but calpionellids were not observed. The lack of Crassicollaria brevis and Calpionella alpina in the samples/thin-sections MG-109 to 114 suggests a rather low stratigraphical position of these limestone beds in the Crassicollaria Zone (Remanei Subzone?).

PLANKTONIC FORAMINIFERS

The Conoglobigerina microfacies occur in the lower part of the Raptawicka Turnia Limestone Formation (lower member, Oxfordian, Fig. 3). In contrast, planktonic foraminifers are un- common in the Kimmeridgian-Tithonian limestones exposed on the Mały Giewont slope (Fig. 11). The Kimmeridgian limestones contain representatives of the genus Conoglobigerina Morozova, emended by Simmons et al. (in: BouDagher-Fadel et al., 1997; Fig. 11B, C, E), and also Haeuslerina Simmons, BouDagher-Fadel, Banner and Whittaker 1997 (Fig. 11D). According to Hart et al. (2012), differentiation between Conoglobigerina and Globuligerina Bignot and Guyader is difficult or even impossible and the status of Haeuslerina is also debatable. The specimens identified as Compactogerina cf. stellapolaris (Grigelis) (Fig. 11A), Conoglobigerina cf. terquemi (lovčeva and Trifonova) (Fig. 11F) and Conoglobigerina sp. occur in the Lower Tithonian limestones; in contrast, planktonic foraminifers were not found in the Upper Tithonian strata (Fig. 2 , section A).

BENTHIC FORAMINIFERS

Benthic foraminifers are moderately common in the limestones of the RTL Fm. In the sections studied, representatives of the genera Lenticulina Lamarck (Fig. 12A-E) and Spirillina Ehrenberg (Fig. 12I, J) are common. Moreover, the presence of the following taxa was recorded: Dentalina cf. jurensis (Gümbel) (Fig. 12F), Ophthalmidium sp. ex gr. O. carinatumtenuissimum (Fig. 12G), Lingulina sp. cf. L. franconica (Gümbel) (Fig. 12H), Glomospira variabilis (Kübler and Zwingli) (Fig. 12K), Reophax sp. (Fig. 12L), Paalzowella feifeli (Paalzow) (Fig. 12M), Protomarssonella cf. dumortieri (Schwager) (Fig. $12 \mathrm{~N}$ ), Pseudomarssonella cf. bipartita Redmond (Fig. 13A), Redmondoides sp. (Fig. 13B), Textularia sp. cf. T. catenata Cushman (Fig. 13C), Textularia jurassica Gümbel (Fig. 13I), Paleogaudryina heersumensis (Lutze) (Fig. 13D), Paleogaudryina sp. aff. P. heersumensis (Lutze) (Fig. 13E), Ammobaculites sp. cf. A. coprolithiformis (Schwager) (Fig. 13F), Ammobaculites sp. (Fig. 13G) and Troglotella incrustans(?) Wernli and Fookes (Fig. 13H).

The stratigraphical value of the above-listed taxa is limited, because of their wide range usually embracing the Kimmeridgian-Tithonian interval, in places also a part of the Lower Cretaceous (Krajewski and Olszewska, 2007; Olszewska, 2010; Olszewska et al., 2012). However, these benthic foraminifers provide additional information about the depositional environment of the Upper Jurassic limestones studied. According to Mišík (1998), the microoncoids of the Kimmeridgian-Tithonian occurring in the RTL Fm contain exclusively planktonic microorganisms. However, some Tithonian microoncoids have been developed around the benthic foraminifers (Fig. 13C).

\section{KIMMERIDGIAN AMMONITES}

Passendorfer (1928) found a few ammonites, brachiopods and aptychi in the Mały Giewont area. His fauna was collected from a grey limestone, $\sim 50 \mathrm{~m}$ above the Bathonian red limestone (Passendorfer, 1951). Owing to J. Lefeld's information (pers. comm., 1989), the exact position of that Kimmeridgian fauna may be located $51 \mathrm{~m}$ above the base of the Raptawicka Turnia Formation (Figs. $1 \mathrm{C}$ and 3 , section $\mathrm{B}$, site a). Passendorfer (1928) identified the following ammonite taxa: Oppelia pseudoflexuosa Favre, Aspidoceras cf. episoides Fontannes, Phylloceras sp. cf. tortisulcatus d'Orbigny, Haploceras sp., Oppelia sp., Perisphinctes sp. and Simoceras sp. Lefeld and Radwański (1960: p. 601) mentioned the taxon Sowerbyceras cf. tortisulcatum (d'Orbigny), instead of Phylloceras sp. cf. tortisulcatus d'Orbigny. 

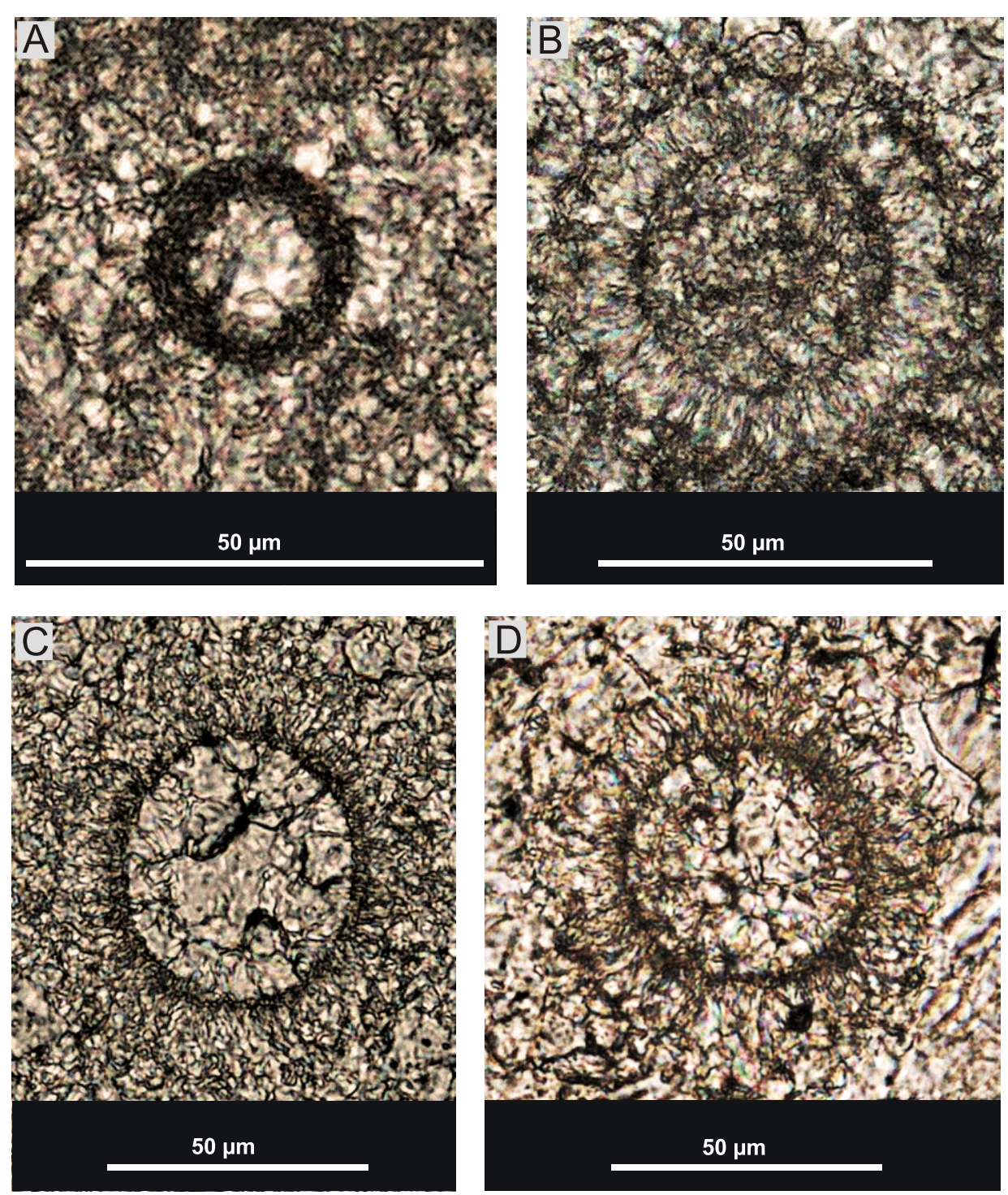

Fig. 6. Calcareous dinoflagellate cysts from the Lower Kimmeridgian strata exposed in section B (Fig. 3) on the western slope of Mały Giewont Mount

A - Cadosina parvula Nagy, thin-section G-6; B - Colomisphaera lapidosa (Vogler), thin-section G-19; C, D - C. nagyi (Borza), thin-sections G-8 and G-19, respectively

According to Passendorfer (1928), this assemblage corresponds to the Aspidoceras acanthicum beds of Kimmeridgian age (Oppelia tenuilobata and Waagenia Beckeri zones). Passendorfer (1928: p. 495) referred to the problem concerning the separation of "O. compsa from O. pseudoflexuosa" mentioned by Fontannes (1879), but could not take a stand in that discussion. Baudouin et al. (2011) included Oppelia pseudoflexuosa Favre, 1877 in the taxon Taramelliceras compsum (Oppel, 1863), as the 3rd stage of ontogeny (macroconchs of $T$. compsum from 30 to $40 \mathrm{~mm}$ across). Checa Gonzalez (1985) included Aspidoceras episoides Fontannes, 1879 in the synonymy of Schaireria episa (Oppel). The stratigraphical range of Schaireria episa was restricted to the Lower Tithonian (Checa Gonzalez, 1985; see also Ohmert and Zeiss, 1980). However, Berckhemer and Hölder (1959) and Hölder and Ziegler (1959) reported this taxon (as Aspidoceras episum) also from the Upper Kimmeridgian Beckeri Zone (Fig. 14). A few specimens identified as Simoceras sp. and similar to Simoceras doublieri d'Orbigny (Passendorfer, 1928: p. 494), were not figured. Later, Passendorfer (1951) mentioned Simoceras aff. doublieri d'Orbigny as occurring in the ammonite assemblage discussed. As shown in Figure 14, Nebrodites (Nebrodites) doublieri (d'Orbigny) was reported to occur from the topmost part of the Strombecki Zone throughout the Divisum Zone of the Lower Kimmeridgian (Olóriz Sáez, 1978). In Italy, its range was shown in the lower part of the Compsum/Acanthicum Zone (Upper Kimmeridgian - Sarti, 1985, 1986, 1993).

In terms of the modern ammonite zonation, the existing data still do not allow exact definition of the age of the Kimmeridgian fauna reported by Passendorfer $(1928,1951)$. The co-occurrence of Taramelliceras compsum (sensu Baudouin et al., 2011) and N. (Nebrodites) aff. doublieri may indicate the stratigraphical interval comprising the Divisum and Compsum/Acanthicum Zones (Fig. 14). However, the presence of Aspidoceras 

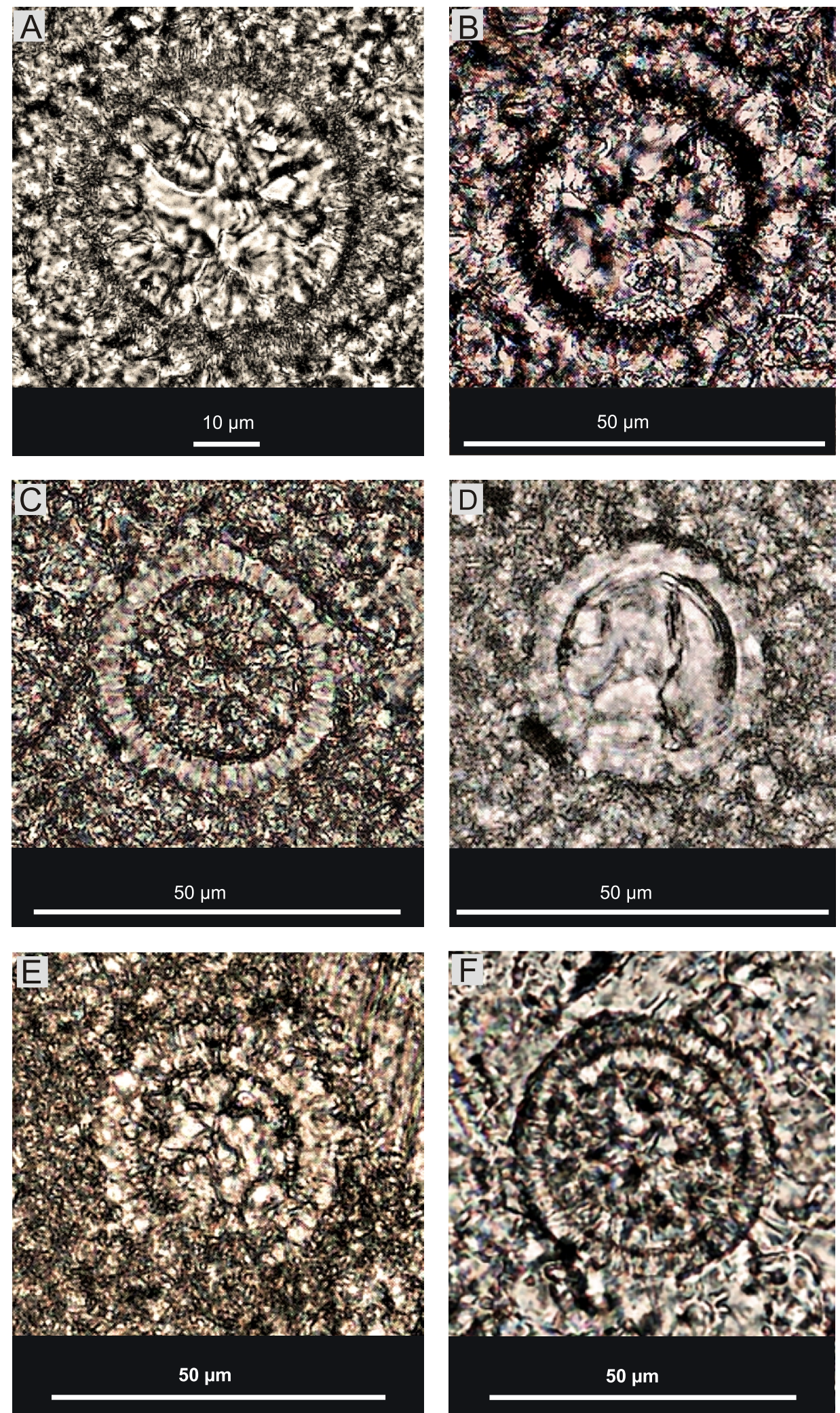

Fig. 7. Calcareous dinoflagellate cysts from sections $A(A-C, F)$ and $B(D-E)$

A - Colomisphaera pieniniensis (Borza), thin-section MG-59 (Lower Kimmeridgian); B - C sublapidosa (Vogler), thin-section MG-87 (Upper Kimmeridgian); C - Stomiosphaera moluccana Wanner, thin-section MG-88 (Upper Kimmeridgian); D - St. moluccana Wanner, thin-section G-44 (uppermost Kimmeridgian); E - Carpistomiosphaera borzai (Nagy), thin-section G-44 (uppermost Kimmeridgian); F - Ca. borzai (Nagy), thin-section MG-89 (uppermost Kimmeridgian) 

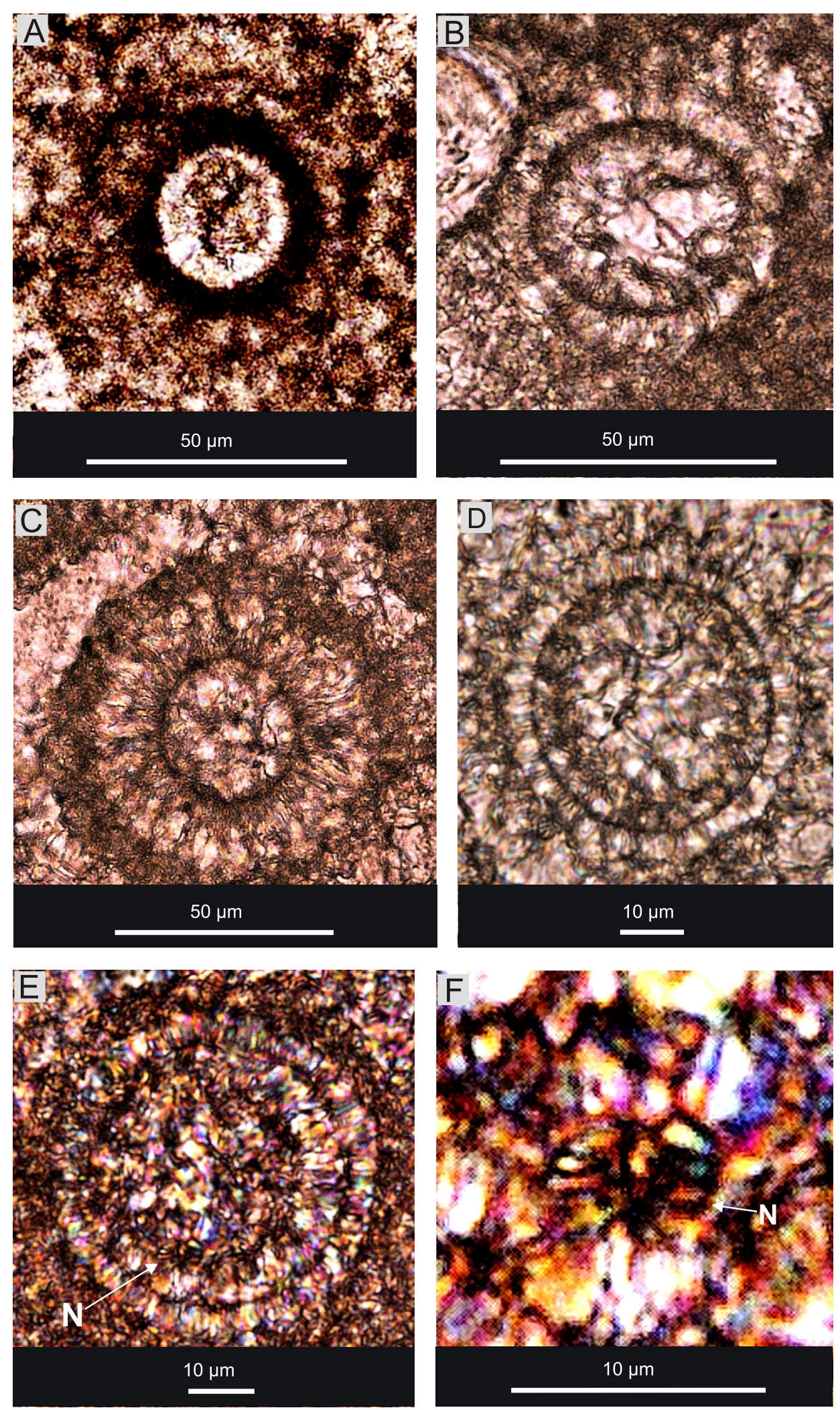

Fig. 8. Calcareous dinoflagellate cysts and Nannoconus from the Lower Tithonian limestones of the Mały Giewont area, section B (Fig. 3)

A - Colomisphaera cf. pulla (Borza), thin-section G-46; B - C. sublapidosa (Vogler), thin-section G-47; C - C. carpathica (Borza), thin-section G-49; D - Parastomiosphaera malmica (Borza), thin-section G-54; E - P. malmica (Borza, 1964) with Nannoconus globulus minor Bralower (N) in deposit filling the dinocyst (thin-section G-56, crossed polars); $\mathbf{F}$ - enlarged fragment of Figure $7 \mathrm{E}$ showing N. globulus minor Bralower (N) 

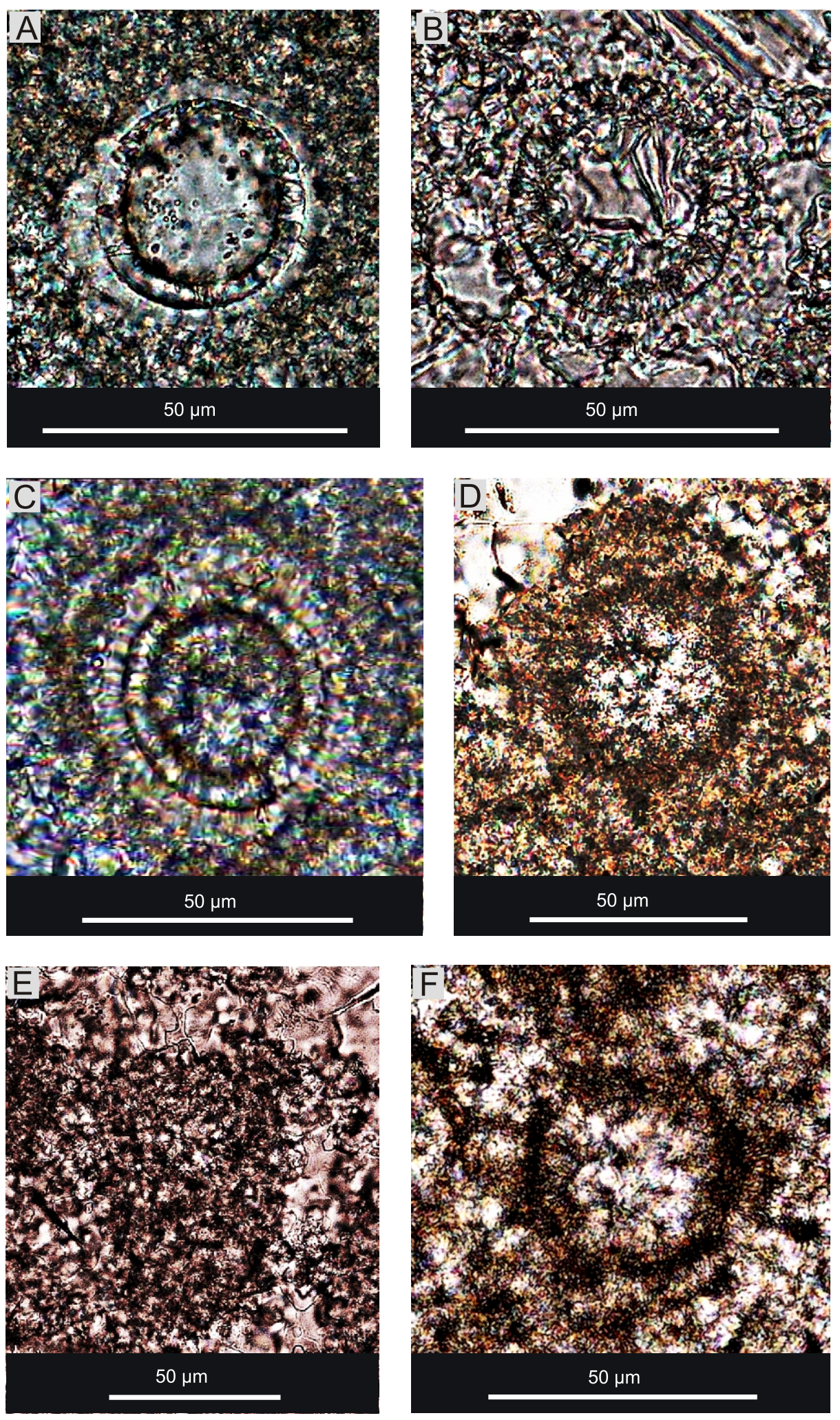

Fig. 9. Tithonian microfossils from the Mały Giewont area

A, B - Parastomiosphaera malmica (Borza), thin-sections MG-99A and MG-101, respectively (Lower Tithonian, section A); C - P. malmica (Borza), thin-section G-57 (Lower Tithonian, section B); D - Dobeniella sp., Chitinoidella Zone, Tithonian (thin-section MG-106, section A); E Chitinoidella cf. elongata Pop, thin-section MG-107, section A (Chitinoidella Zone, Tithonian); F Borziella cf. slovenica (Borza), thin-section G-66, section B (Chitinoidella Zone, Tithonian) 

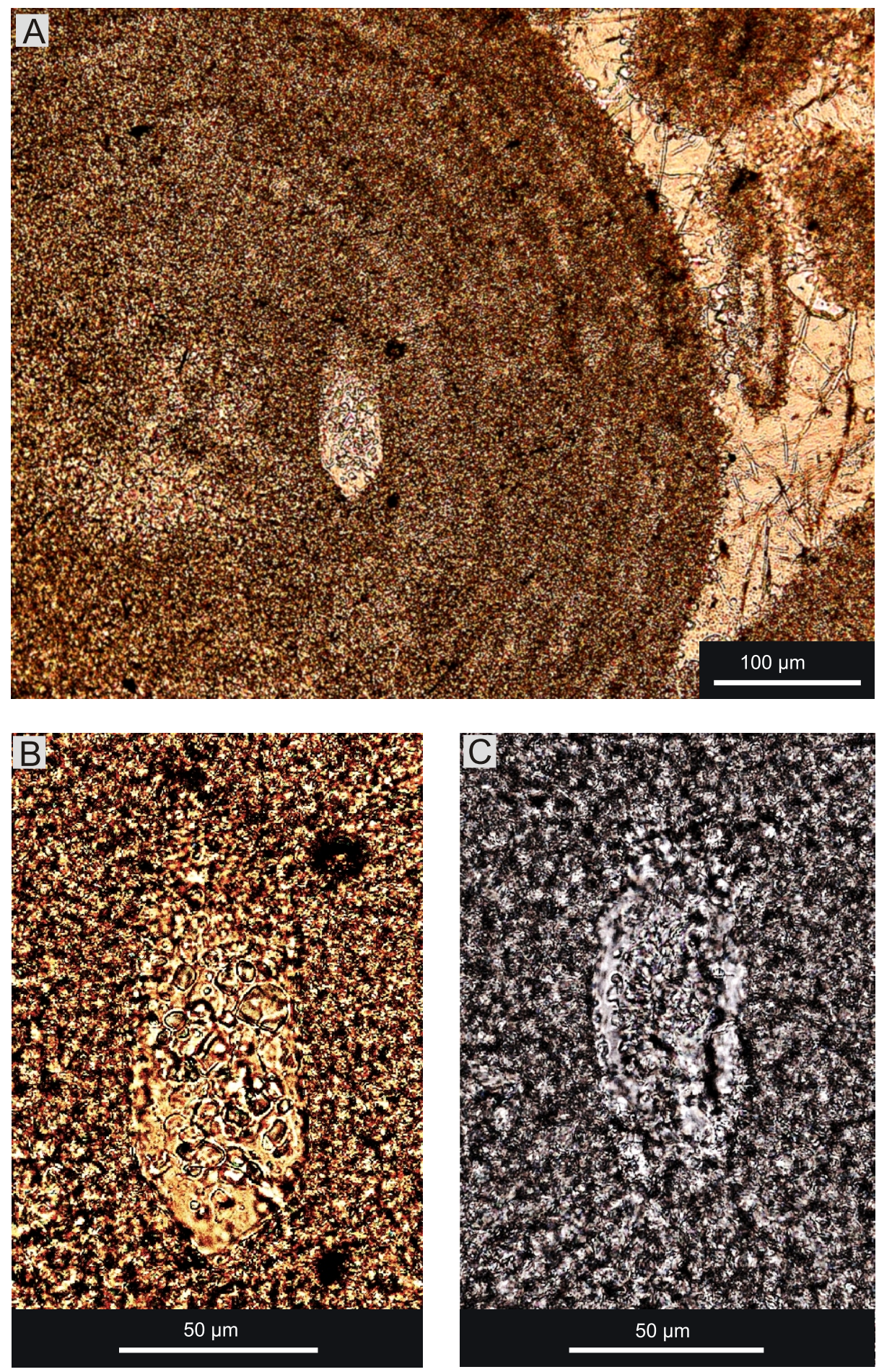

Fig. 10. Calpionellids occurring within microoncoids from the Upper Tithonian limestones of the section A of the Mały Giewont area

A - Tintinnopsella carpathica (Murgeanu and Filipescu), thin-section MG-110, Crassicollaria Zone; B - enlarged fragment of Figure 9A: Tintinnopsella carpathica (Murgeanu and Filipescu), thin-section MG-110; C - Crassicollaria cf. parvula Remane, thin-section MG-115, Crassicollaria Zone

cf. episoides [= Sch. cf. episa (Oppel)] is not in accordance with this interpretation and suggests a younger age of the whole ammonite assemblage. The whorl cross-section of the specimen (Passendorfer, 1928: pl. XXX, fig. 4b) is also similar to that of Schaireria neumayri Checa, a species created 57 years after
E. Passendorfer's publication (Checa Gonzalez, 1985). In the Cordilleras Beticas (Spain), Schaireria neumayri is known from the Kimmeridgian (Compsum Zone) to the Lower Tithonian (Checa Gonzalez, 1985: p. 186). 

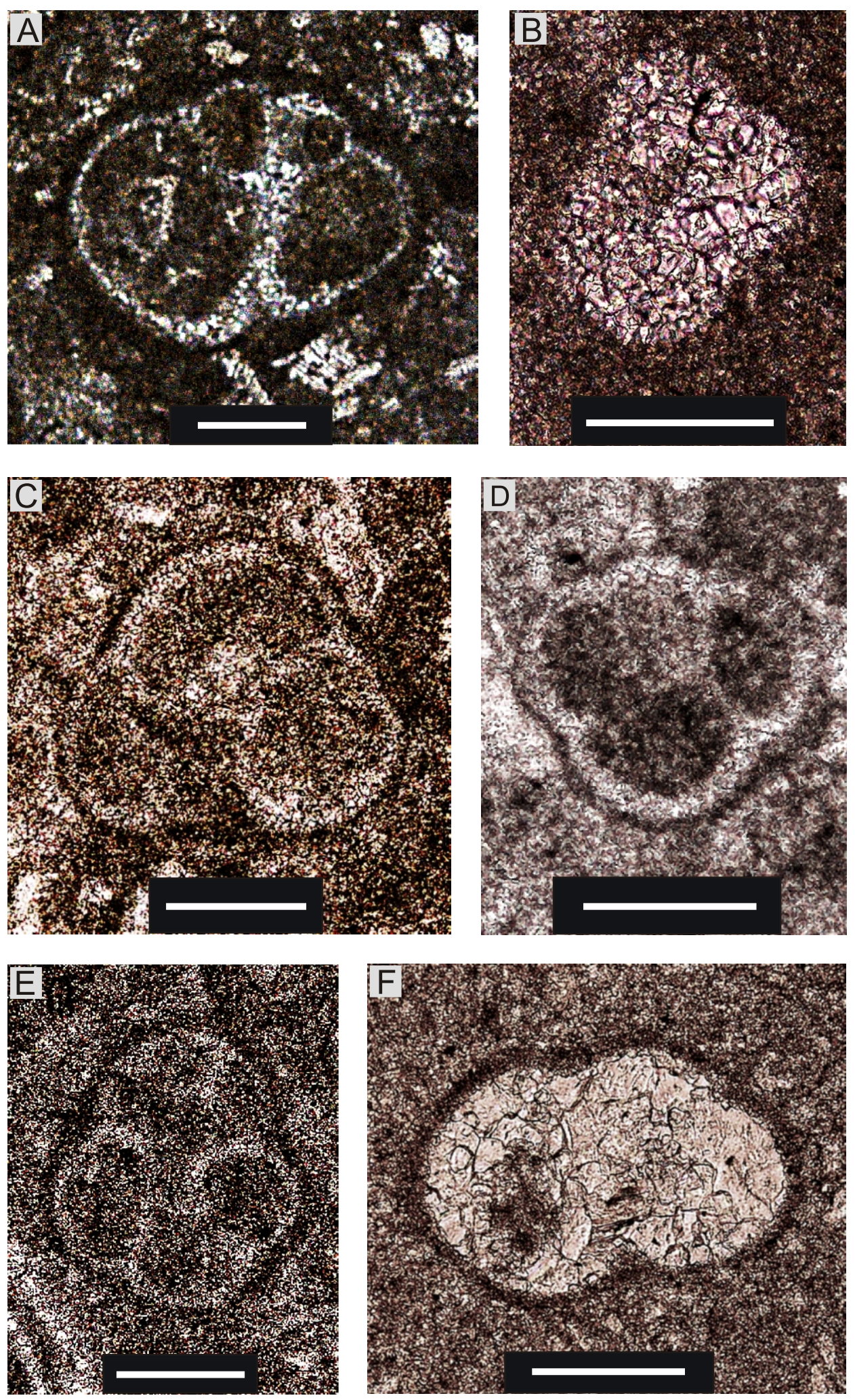

Fig. 11. Conoglobigerinidae from the Kimmeridgian-Tithonian strata of the Raptawicka Turnia Limestone Formation, Mały Giewont area, Western Tatra Mountains (scale bar $=100 \mu \mathrm{m}$ )

A - Compactogerina cf. stellapolaris (Grigelis), thin-section MG-95 (section A), Lower Tithonian; B Conoglobigerina sp. cf. C. bathoniana (Pazdrowa), thin-section MG-81 (section A), Upper Kimmeridgian; C - Conoglobigerina sp. cf. C. bathoniana (Pazdrowa), thin-section G-4 (section B), Lower Kimmeridgian; D - Haeuslerina sp. cf. H. parva (Kuznetsova), thin-section MG-65 (section A), Lower Kimmeridgian; E - C. sp. ex gr. C. bathoniana-oxfordiana, thin-section MG-58 (section A), Lower Kimmeridgian; F - C. cf. terquemi (lovčeva and Trifonova), thin-section G-50 (section B), Lower Tithonian 

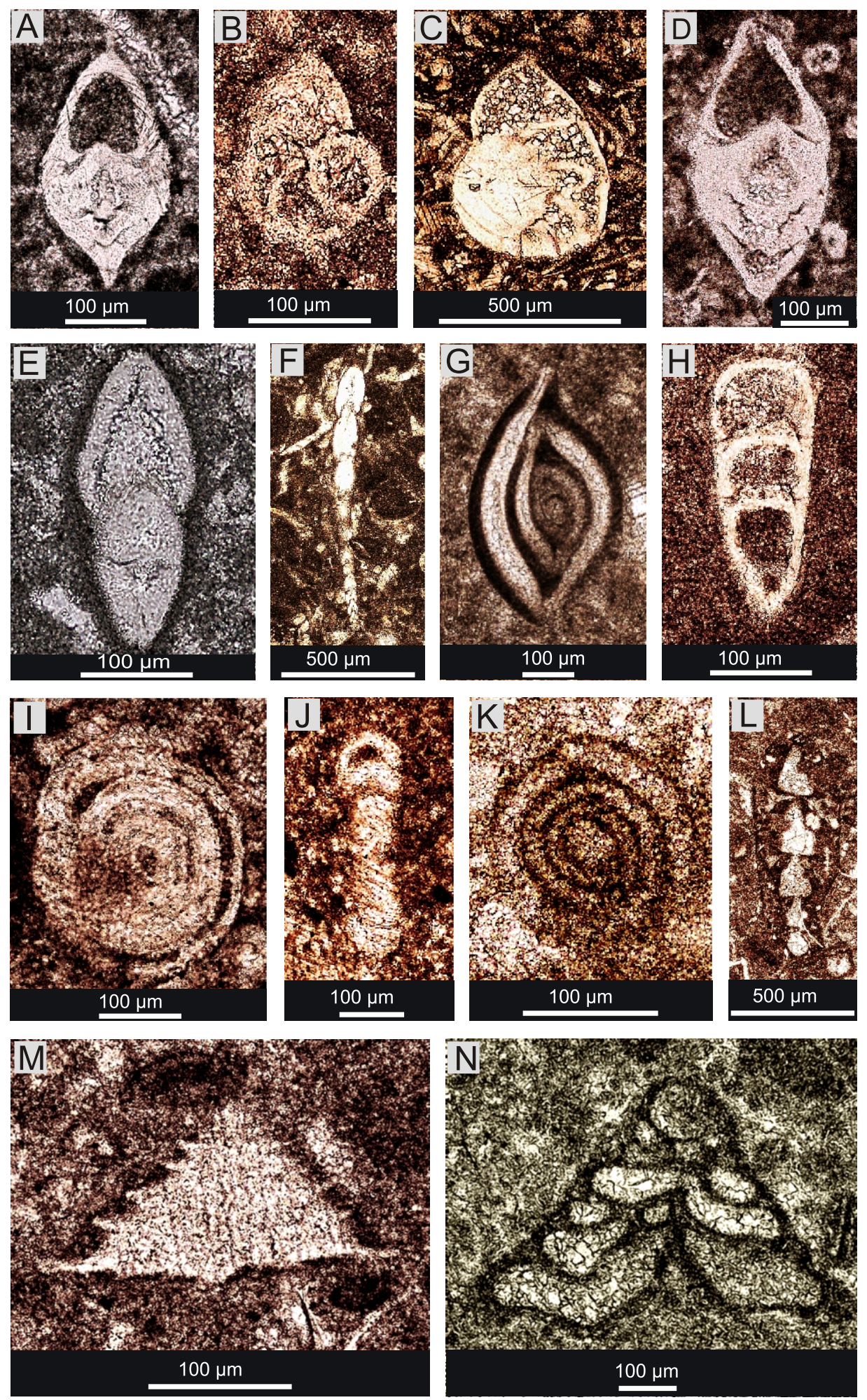

Fig. 12. Benthic foraminifers from the Kimmeridgian-Tithonian limestones of the Mały Giewont area

A - Lenticulina cf. uhligi (Wiśniowski), thin-section MG-56 (section A), Lower Kimmeridgian; B - L. sp., thin-section G-38 (section B), Upper Kimmeridgian; C - L. cf. muensteri (Reuss), thin-section MG-84 (section A), Upper Kimmeridgian; D - L. cf. muensteri (Reuss), thin-section MG-91 (section A), Lower Tithonian; E - L. cf. biexcavata (Mjatliuk, 1939), thin-section MG-95A (section A), Lower Tithonian; F - Dentalina cf. jurensis (Gümbel), thin-section G-45 (section B), Lower Tithonian; G - Ophthalmidium sp. ex gr. O. carinatum-tenuissimum, thin-section G-33 (section B), Upper Kimmeridgian; H - Lingulina sp. cf. L. franconica (Gümbel), thin-section G-61 (section B), Lower Tithonian; I - Spirillina sp. ex gr. S. tenuissima-polygyrata, thin-section G-42 (section B), uppermost Kimmeridgian; J - S. sp., thin-section G-41 (section B), Upper Kimmeridgian; K - Glomospira variabilis (Kübler and Zwingli), thin-section G-37 (section B), Upper Kimmeridgian; L - Reophax sp., thin-section G-58 (section B), Lower Tithonian; M - Paalzowella feifeli (Paalzow), thin-section G-45 (section B), Lower Tithonian; N - Protomarssonella cf. dumortieri (Schwager), thin-section MG-60 (section A), Lower Kimmeridgian 

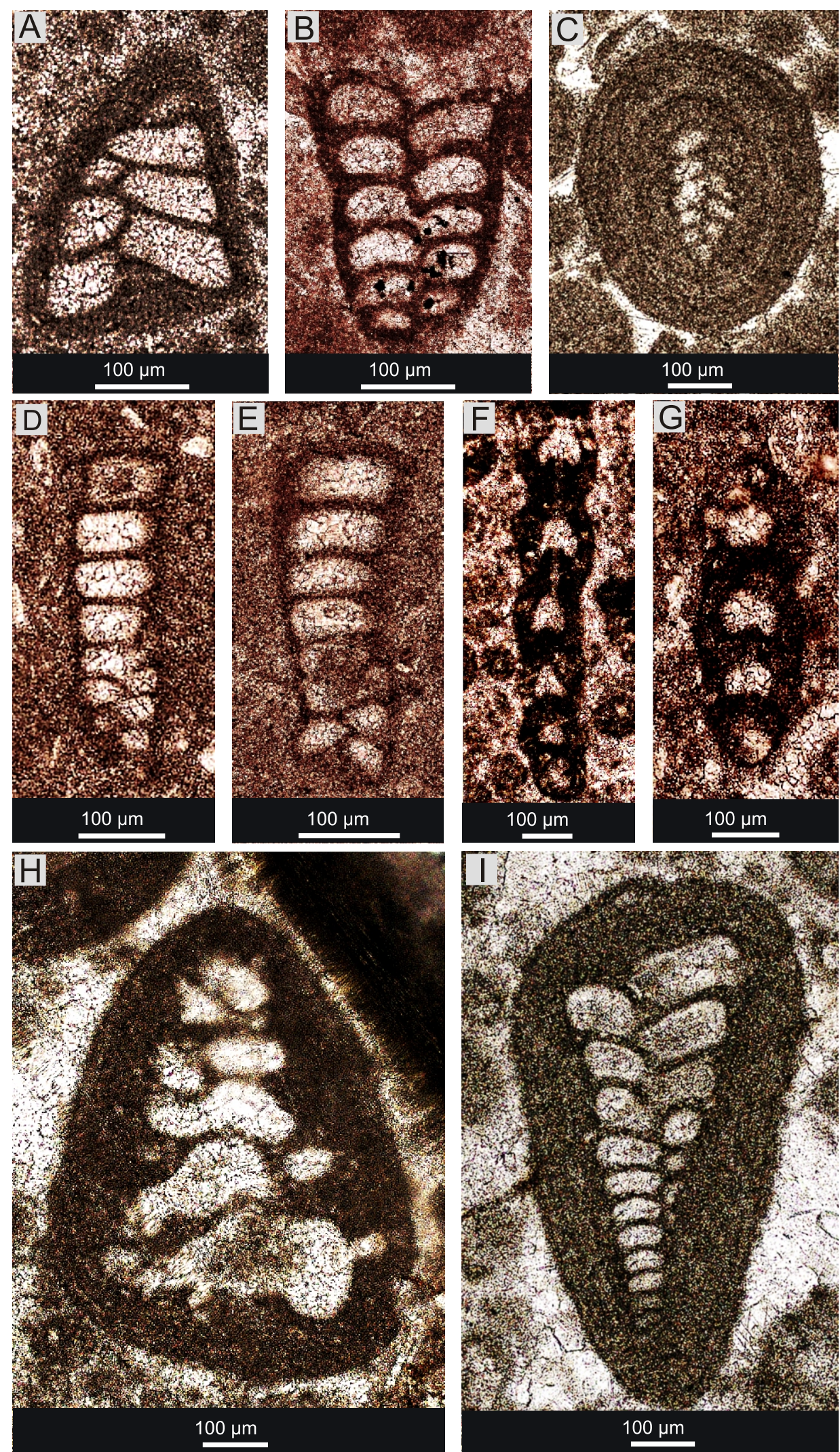

Fig. 13. Benthic foraminifers from the Kimmeridgian-Tithonian limestones of the Mały Giewont area (continuation)

A - Pseudomarssonella cf. bipartita Redmond, thin-section G-57 (section B), Lower Tithonian; B - Redmondoides sp., thin-section G-53 (section B), Lower Tithonian; C - Textularia sp. cf. T. catenata Cushman (as a microoncoid nucleus), thin-section G-69 (section B), Chitinoidella Zone, Tithonian; D - Paleogaudryina heersumensis (Lutze), thin-section G-35 (section B), Upper Kimmeridgian; E - Paleogaudryina sp. aff. P. heersumensis (Lutze), thin-section G-56 (section B), Lower Tithonian; F - Ammobaculites sp. cf. A. coprolithiformis (Schwager), thin-section MG-63 (section A), Lower Kimmeridgian; G - Ammobaculites sp., thin-section G-34 (section B), Upper Kimmeridgian; H - Troglotella incrustans (?) Wernli and Fookes coated by microbial filaments 0.3-1.0 $\mu \mathrm{m}$ in diameter (Cyanobacteria), thin-section G-67 (section B), Chitinoidella Zone, Tithonian; I - Textularia jurassica Gümbel, coated by microbial filaments 0.3-1.0 $\mu \mathrm{m}$ in diameter, thin-section G-68 (section B), Chitinoidella Zone, Tithonian 


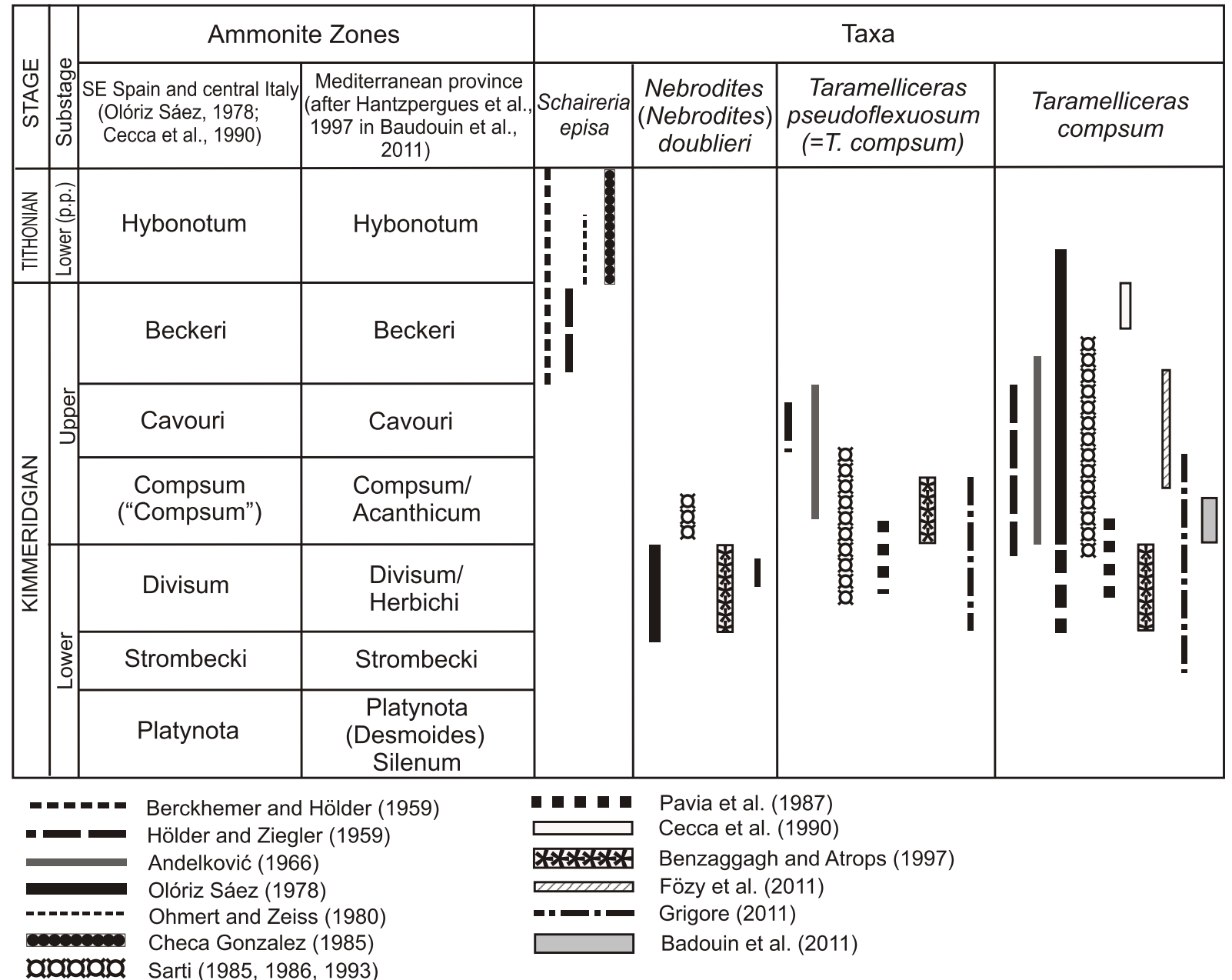

Fig. 14. Ranges of selected Kimmeridgian-Early Tithonian ammonite taxa after cited authors

According to the Italian authors (Pavia et al., 1987; Sarti, 1990), Sowerbyceras tortisulcatum (d'Orbigny) occurs in the Oxfordian, whereas S. loryi (Munier Chalmas) is known from the Kimmeridgian. Although Andelković (1966) illustrated one specimen of $S$. tortisulcatum from the Lower Kimmeridgian Physodoceras uhlandi Zone (or Subzone), Sarti (1990) included his specimen in the synonymy of $S$. loryi. The occurrence of Taramelliceras ex gr. compsum (Oppel) above the fauna collected by Passendorfer (1928) (see below) and new microfossil data exclude a latest Kimmeridgian-Early Tithonian age of the ammonites discussed. The microfossil stratigraphy, presented above, suggests rather a late Early Kimmeridgian age (acme Parvula Zone) of the ammonite assemblage (site a in Fig. 3) described by Passendorfer (1928).

One specimen of Taramelliceras ex gr. compsum (Oppel) was found in 1990 (section B, site b, bed G-33 in Fig. 3), 14 m above the base of the beds with the Kimmeridgian fauna found by Passendorfer (1928). The ammonite was collected from the grey pseudonodular biooncosparite, which contained also other poorly preserved macrofossils (one belemnite and a few echinoderm fragments). This ammonite (Fig. 15) was kindly identified by Dr. Federico Olóriz Sáez of the University of Granada (Spain). According to him (written information), the specimen is a phragmocone, perhaps with the initial part of the living chamber preserved only. The taxon $T$. ex gr. compsum in- dicates probably the Middle Kimmeridgian (Compsum-Cavouri zones in southern Spain), although may occur also in the Upper Kimmeridgian (Beckeri Zone).

Based on the above opinion, the lithostratigraphical position of bed G-33 (Fig. 3) and new microfossil data (this paper) it must be concluded that Taramelliceras ex gr. compsum was found in Upper Kimmeridgian strata (in the bipartite subdivision of the Kimmeridgian Stage - Fig. 14). The pseudonodular biooncosparite with Taramelliceras ex gr. compsum (sample G-33, site b-Fig. 3) occurs in the upper part of the Moluccana Zone within the topmost interval of the Bositra-Saccocomidae MF (see the next section). The specimen of Taramelliceras ex gr. compsum was collected from the strata probably corresponding to the Cavouri or Beckeri (lower part) ammonite zones.

\section{MICROFACIES}

Three microfacies (MF) are distinguished in section A (Fig. 2) in the Kimmeridgian-Tithonian limestones: a Globochaete-Saccocomidae MF (G-SA), a Bositra-Saccocomidae MF (B-SA) or its variant - a Bositra-Saccocomidae-Globochaete MF (B-SA-G) (Fig. 16B) and a Saccocoma-Globochaete MF (SA-G) (Fig. 17A). In section B (Fig. 3), the following micro- 

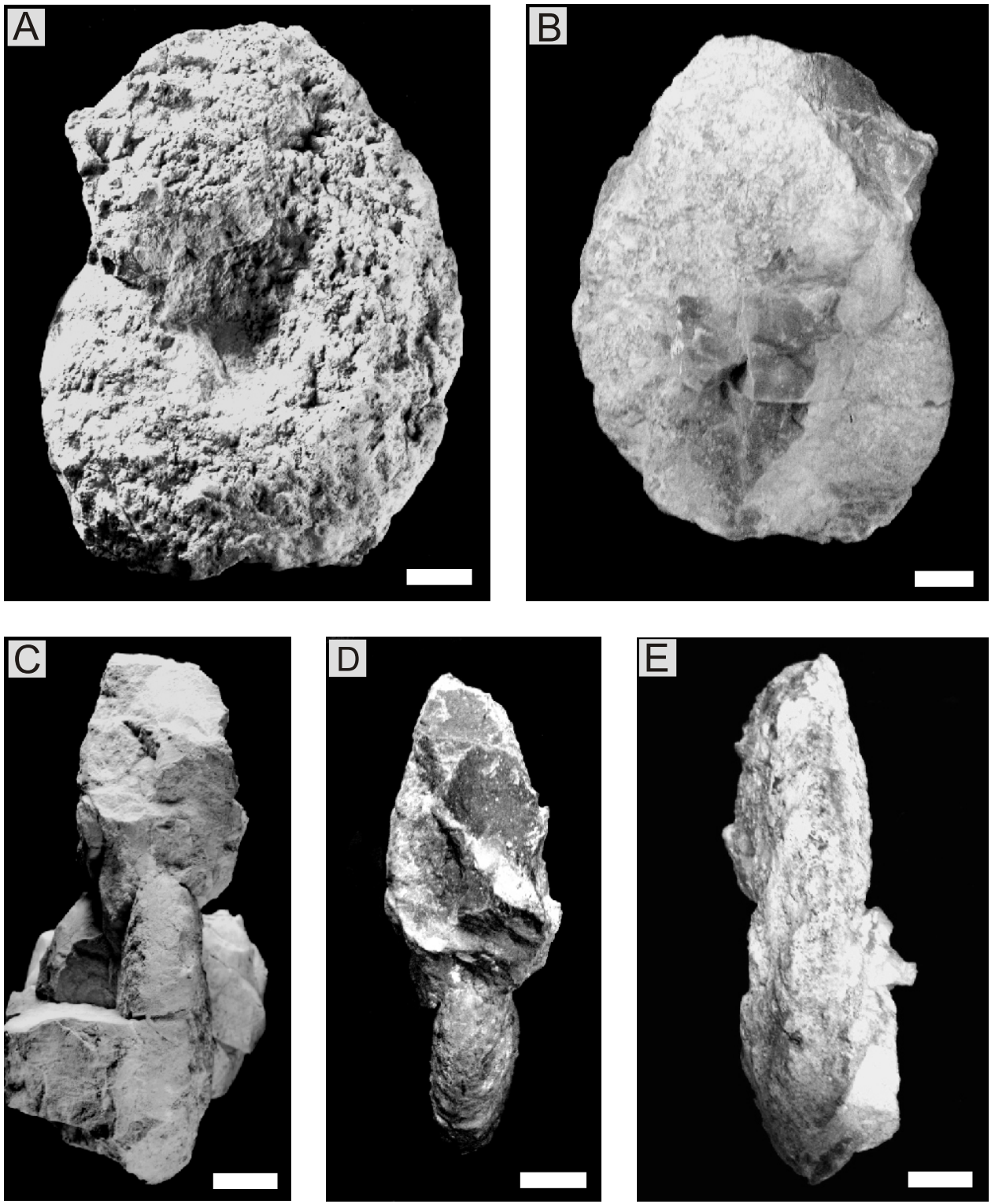

Fig. 15. Taramelliceras ex gr. compsum (Oppel) found in the limestone bed labelled as site B, together with the sample G-33 (section B in Figs. 3 and 4); the ammonite was identified by Dr. F. Olóriz Sáez

A - lateral view of the specimen's left side; $\mathbf{B}$ - lateral view of the right side; $\mathbf{C}$ - frontal view (before the limestone partly covering the specimen's sides was removed); D - frontal view (after the limestone partly covering the specimen's sides was removed and the specimen was rotated around its horizontal axis); $\mathbf{E}$ - ventral view; scale bar $=1 \mathrm{~cm}$

facies are identified: Bositra (Callovian), Conoglobigerina (Oxfordian), Globochaete (Upper Oxfordian-Lower Kimmeridgian - Fig. 16A), Globochaete-Saccocomidae (Lower Kimmeridgian), Bositra-Saccocomidae (Lower-Upper Kimmeridgian), Saccocoma-Globochaete (Upper Kimmeridgian-Lower Tithonian) and Saccocoma (Tithonian - Fig. 17B). Peloids predominate in the Globochaete MF, whereas microoncoids and bioclasts with microbial envelopes or cortoids are common in the last three microfacies types.

The Globochaete MF and Globochaete-Saccocomidae MF probably correspond to microfacies $\mathrm{MF}_{\mathrm{III}}$ (uppermost Oxfordian-Lower Kimmeridgian) on the western margin of the
French Subalpine Basin (Ardèche area - Dromart and Atrops, 1988). The Kimmeridgian Bositra-Saccocomidae microfacies, as well as its variant with Globochaete (Fig. 16B), is an equivalent to microfacies $\mathrm{MF}_{\|}$of the Ardèche area (Dromart and Atrops, 1988: pl. I). In section A this microfacies was found in the $15 \mathrm{~m}$ thick limestones (vs. $17 \mathrm{~m}$ in section B, Fig. 3). Kimmeridgian ammonites (Passendorfer, 1928) have been found in the lower part of the limestones assigned to the Bositra-Saccocomidae MF. Cross-sections of juvenile ammonites are frequently observed in thin sections made of samples taken from the limestones of this microfacies. The Saccocoma-Bositra microfacies was reported from the Moluccana Zone in 

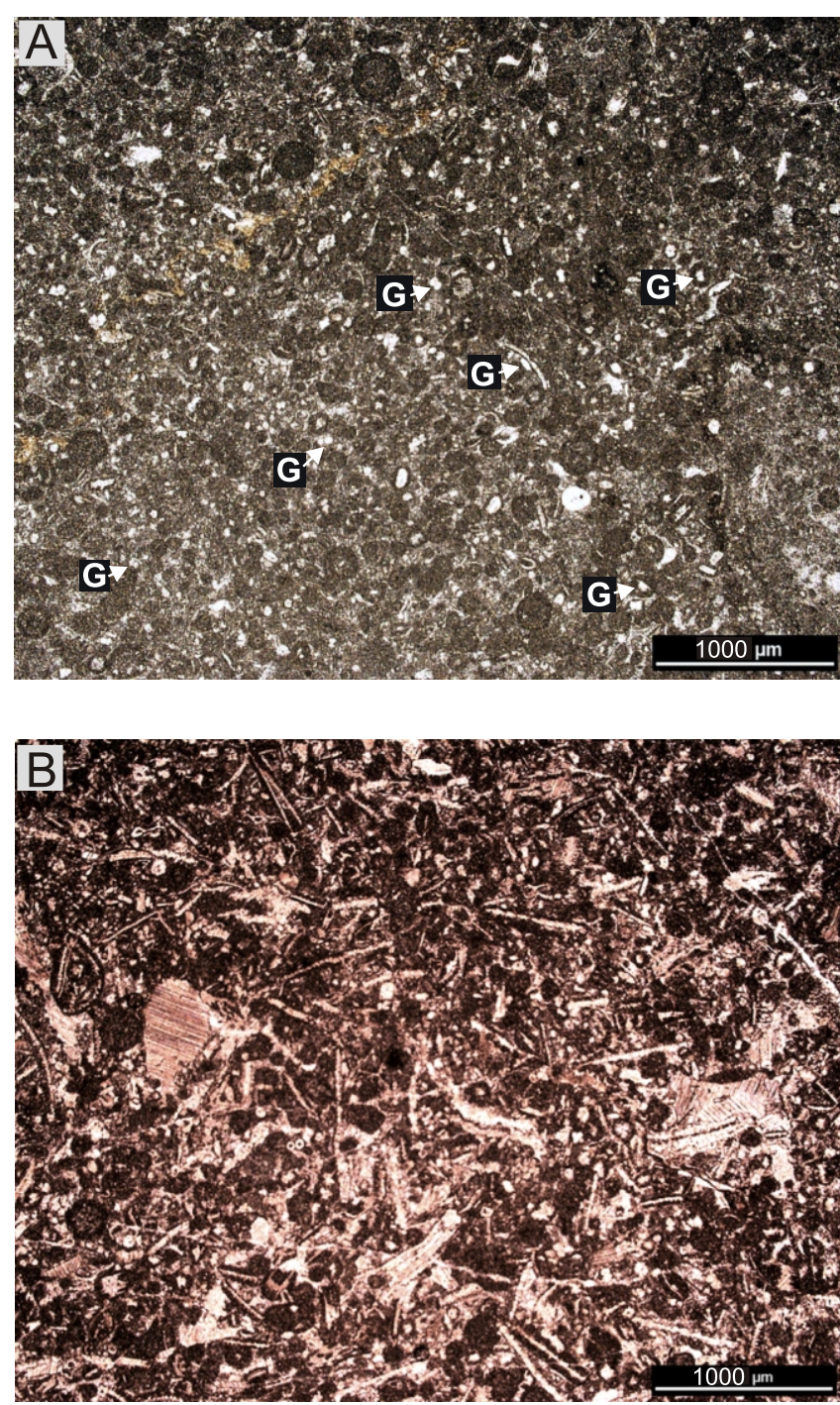

Fig. 16A - Globochaete microfacies (with frequent peloids), Lower Kimmeridgian, thin-section G-4 (section B), G - Globochaete alpina; B - Bositra-Globochaete-Saccocomidae microfacies, Upper Kimmeridgian, thin-section MG-70 (section A)

the Kimmeridgian pelagic limestones of the Długa Valley section (Sub-Tatric Succession, Western Tatra Mountains - Jach et al., 2014).

The grey limestones of the Bositra-Saccocomidae MF are followed by the olive-grey and brownish-grey limestones of the Saccocoma-Globochaete MF (Fig. 17A) and Saccocoma MF (Fig. 17B). These microfacies correspond to $\mathrm{MF}_{\mathrm{I}}$ (Saccocoma) of the Ardèche area (Dromart and Atrops, 1988). In the Mały Giewont area (Fig. 2), the Saccocoma MF continues higher in the Upper Tithonian, because of very scarce occurrence of calpionellids in the limestones belonging to this substage.

\section{CHARACTERISTICS OF THE $\delta^{13} \mathrm{C}$ CURVE} FROM SECTION A

The carbon isotope data are derived from sublittoral marine limestones deposited during the Kimmeridgian and Tithonian on the Upper Jurassic swell (passive Tatric Ridge according to Michalík, 2007). The $\delta^{18} \mathrm{O}$ and $\delta^{13} \mathrm{C}$ curves (Fig. 18A) are based
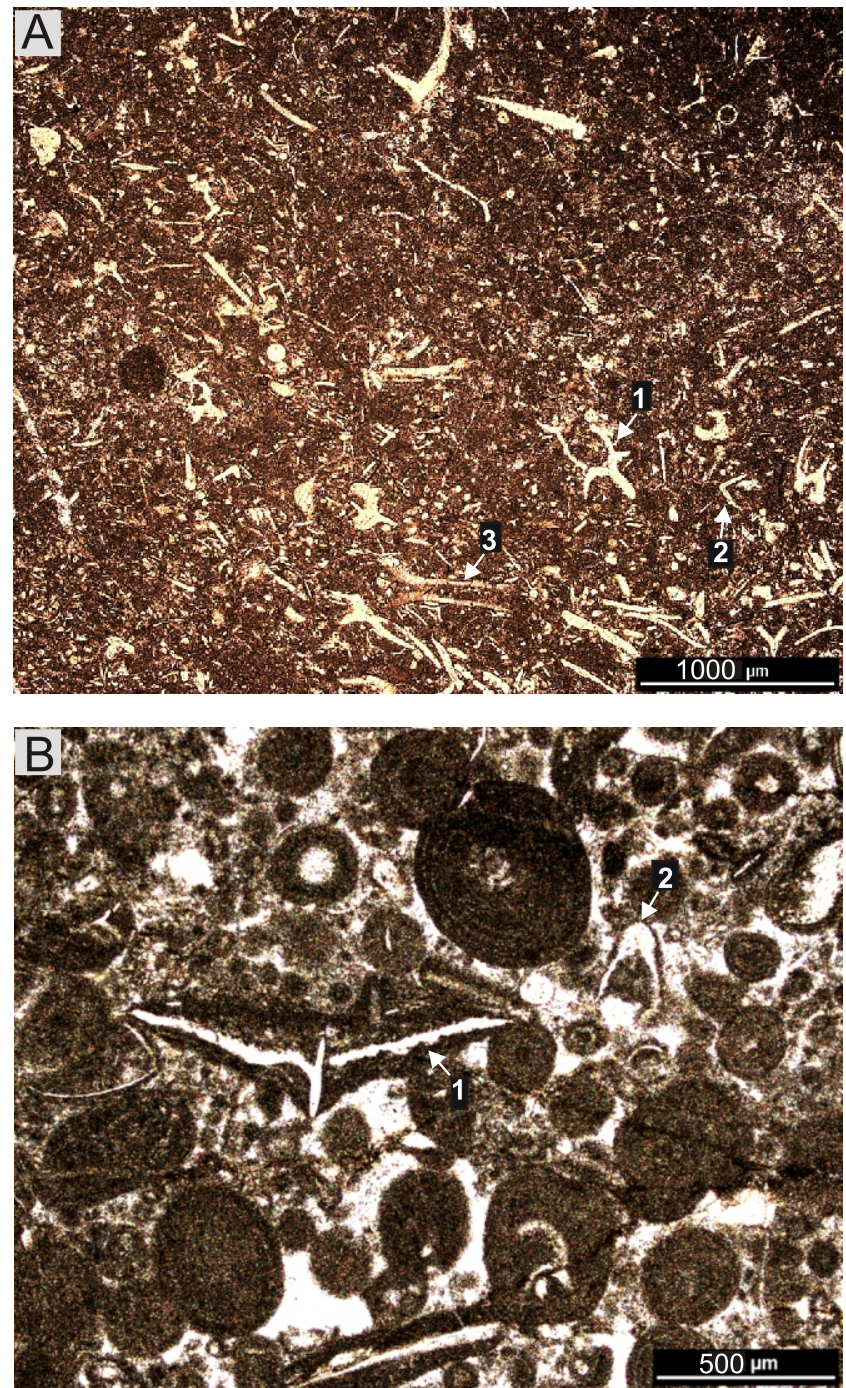

Fig. 17A - Saccocoma-Globochaete microfacies, Upper Kimmeridgian, thin-section MG-87 (section A); 1-3: saccocomid ossicles similar to skeletal sections (respectively) BM, $B T$ and $Y$ shown in Benzaggagh et al. (2015: fig. 17) are also indicated; B - Saccocoma microfacies (1 - wing-shaped section, 2 - skeletal section similar to Figure 13B in Benzaggagh et al., 2015); microoncolithic limestone, Chitinoidella Zone, Tithonian, thin-section G-68 (section B)

on the isotopic values registered from the bulk limestone samples collected from section A (Fig. 2 and Appendix 2).

Values of $\delta^{13} \mathrm{C}$ register between -0.37 and $2.60 \%$ VPDB. If the result for sample MG-98 $(-0.37 \%)$ is omitted, the range of values is $0.97-2.60 \%$ o VPDB only. The range is similar to that registered for the Upper Jurassic pelagic limestones in the Długa Valley (Sub-Tatric Succession), Western Tatra Mountains, located $\sim 4.7 \mathrm{~km}$ to the west of the area shown in Figure $1 \mathrm{~B}$ (cf. Jach et al., 2014: fig. 1). The cross-plot of $\delta^{13} \mathrm{C}$ versus $\delta^{18} \mathrm{O}$ for Mały Giewont shows a weak correlation (Fig. 18B); the most negative $\delta^{13} \mathrm{C}$ values, like those in samples MG-98 and MG-107, indicate that isotopic composition might have been locally altered by burial diagenesis (e.g., Jach et al., 2014). The $\delta^{13} \mathrm{C}$ curves from Mały Giewont and the Długa Valley are correlative in the Kimmeridgian-Lower Tithonian interval (Fig. 19). Therefore the influence of the later diagenetic 


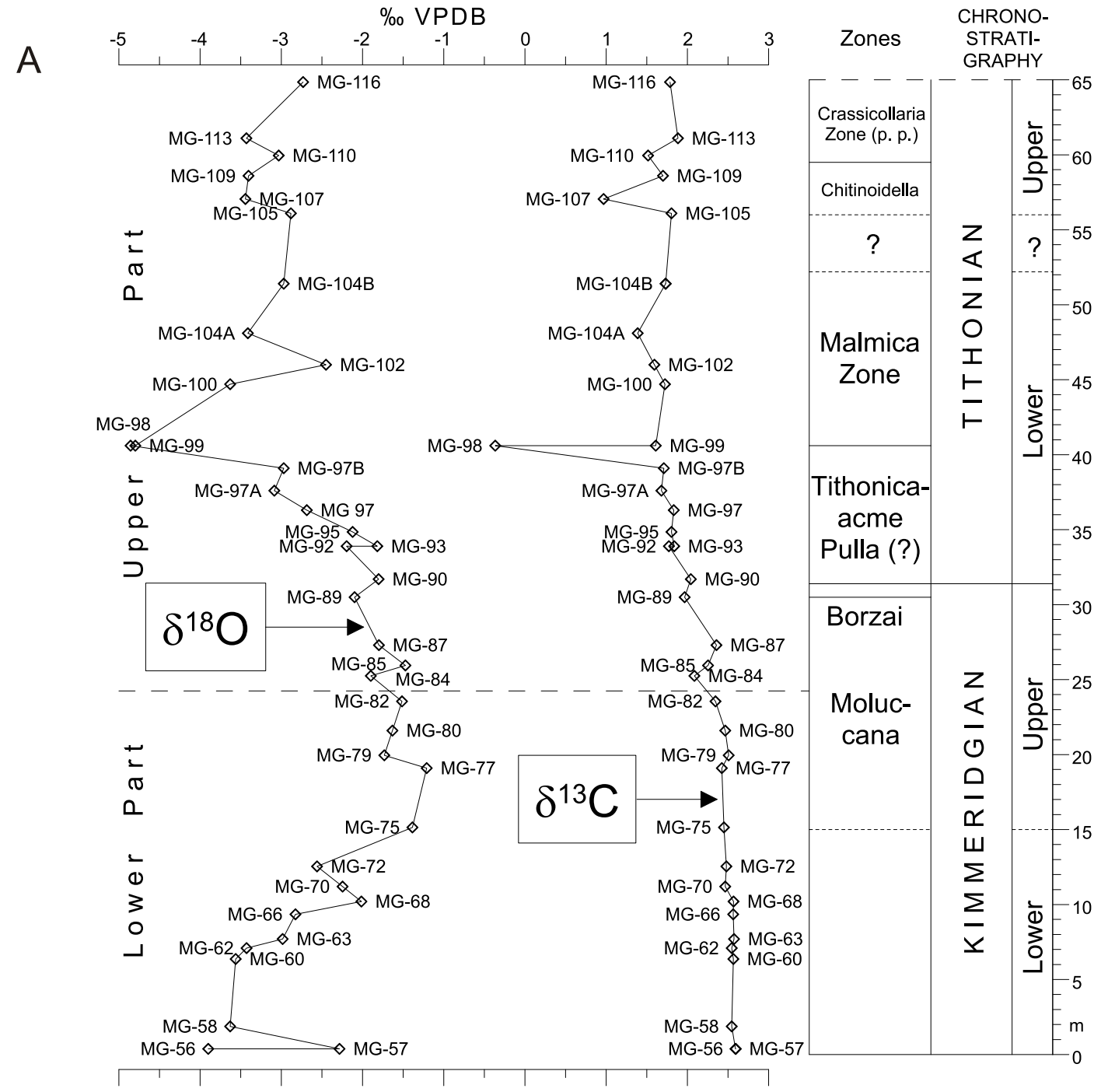

B

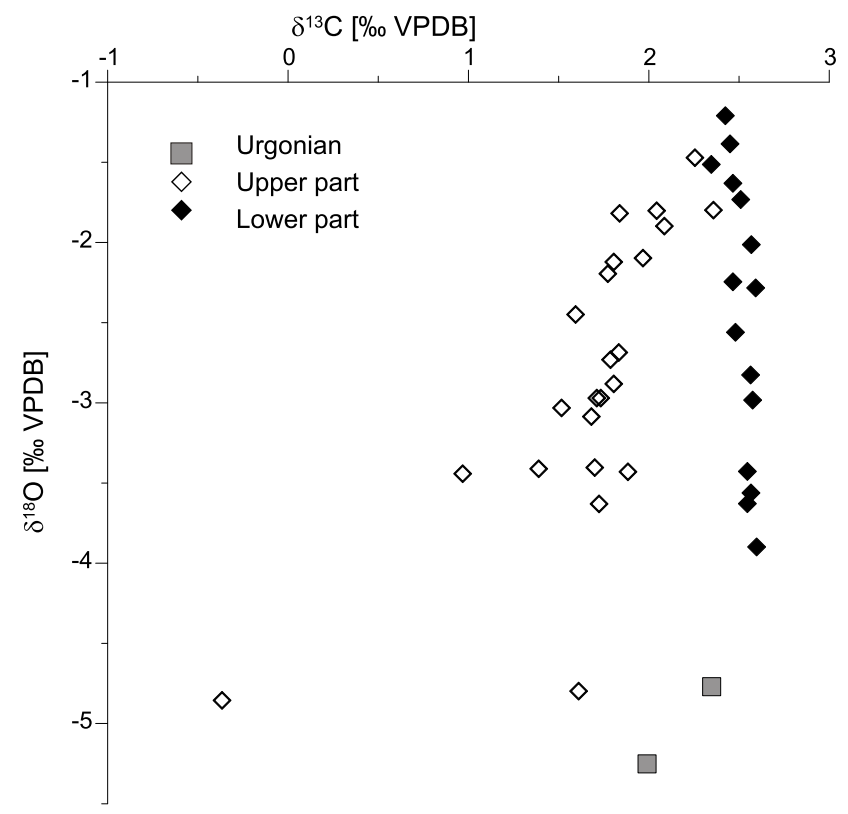

Fig. $18 \mathrm{~A}-\delta^{18} \mathrm{O}$ and $\delta^{13} \mathrm{C}$ curves for the Kimmeridgian-Tithonian interval of the Raptawicka Turnia Limestone Formation in the Mały Giewont area (section A in Fig. 2); a dashed line between samples MG-82 and MG-84 indicates horizon of change in the correlation trends between $\delta^{18} \mathrm{O}$ and $\delta^{13} \mathrm{C}$ values (see Fig. 17B); B cross-plot of $\delta^{18} \mathrm{O}$ and $\delta^{13} \mathrm{C}$ values from section $\mathrm{A}$ in the Mały Giewont area; lower part - samples MG-56 to MG-82; upper part - samples MG-84 to MG-116 


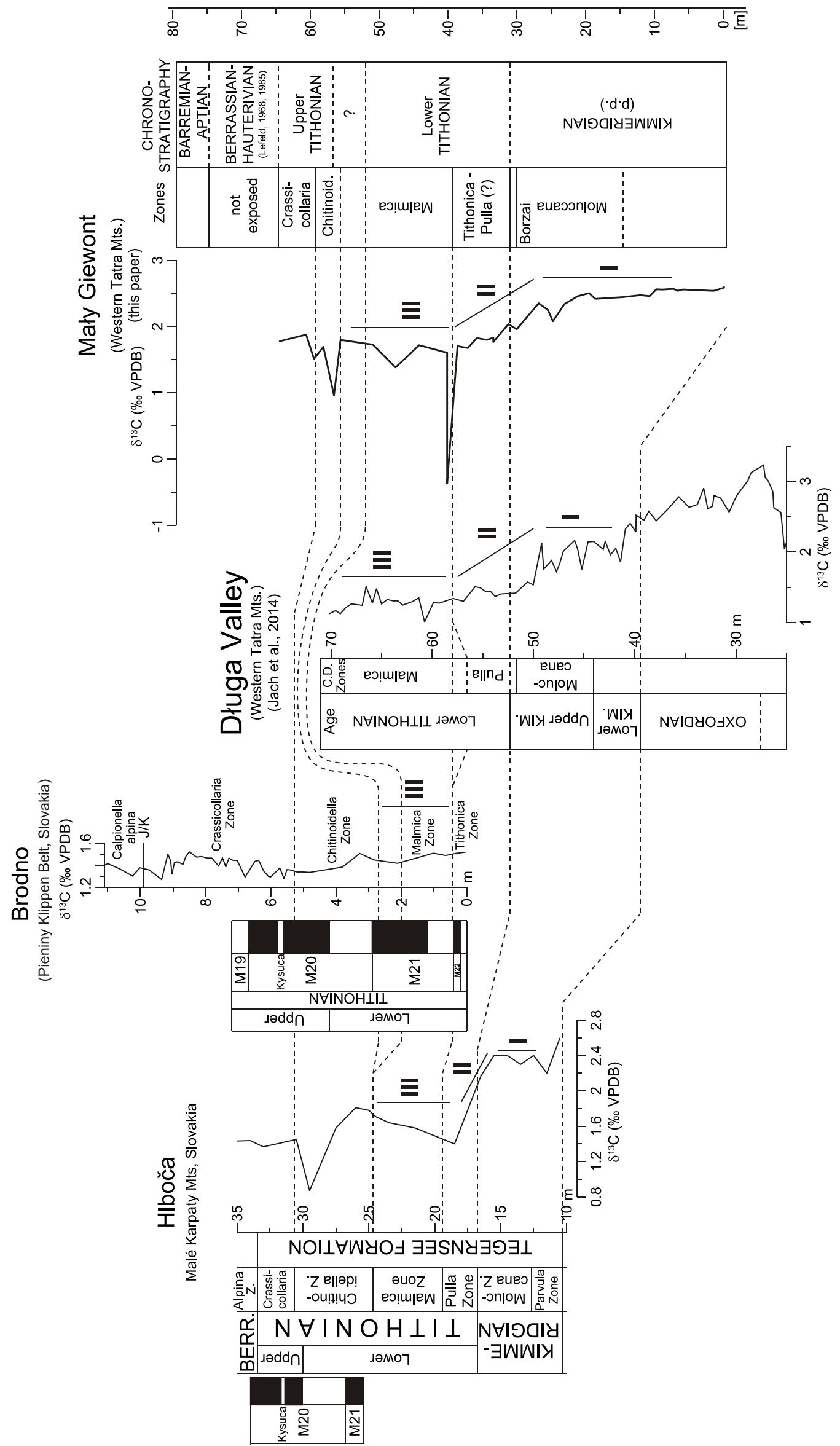


(and tectonic) alterations did not obliterate a primary isotopic signal in the Mały Giewont section (for details, see section "Correlation trends between $\delta^{13} \mathrm{C}$ and $\delta^{18} \mathrm{O}$ data" in the "Discussion" chapter).

In the lowermost part of the $\delta^{13} \mathrm{C}$ curve for section $\mathrm{A}$ of the Mały Giewont area (samples MG-56 to 68 ) the registered values fluctuate around $2.55-2.60 \%$ (Fig. 18A). This interval of the isotopic curve corresponds to the Globochaete-Saccocomidae MF correlated with a part of the acme Parvula Zone in section B (Figs. 3 and 4). The next interval of the $\delta^{13} \mathrm{C}$ curve terminates with the MG-77 (2.42\%), just in the Upper Kimmeridgian Moluccana Zone and within the Bositra-Saccocomidae (B-SA) MF. A minor positive shift relates to sample MG-79 (2.51\%o), and the $\delta^{13} \mathrm{C}$ values diminish to $2.09 \%$ for sample MG-84 (Figs. 18A and 19), still within the Moluccana Zone (Upper Kimmeridgian). This small negative excursion occurs at the upper boundary of the B-SA microfacies (Fig. 2); the next samples (MG-85 and 87) have higher values $(2.36 \%$ for sample MG-87). At the Moluccana-Borzai zonal boundary (Fig. 18A), the registered $\delta^{13} \mathrm{C}$ value for the sample MG-89 is distinctly lower $(1.97 \%$ ).

Sample MG-90 (lowermost Tithonian) denotes a weak positive shift on the $\delta^{13} \mathrm{C}$ curve (Fig. 18A). Subsequent samples with isotopic values as low as $1.71 \%$ occur at the base of the Malmica Zone (Fig. 18A). A spectacular negative excursion $(-0.37 \%$ ) is designated by one sample only (MG-98); however, this sample is cut by numerous (thin) calcite veinlets of tectonic origin. Just for the next analysed sample (MG-100) the isotopic record $\left(\delta^{13} \mathrm{C}\right)$ returns to the former level $(1.72 \%)$ and then diminishes to $1.39 \%$ (sample MG-104A, still within the Malmica Zone - Fig. 18A). The value $0.97 \%$ for sample MG-107 indicates a minimum of the $\delta^{13} \mathrm{C}$ record within the Chitinoidella Zone (Figs. 18A and 19). The $\delta^{13} \mathrm{C}$ values for samples MG-109 to MG-113 are higher (up to $1.88 \%$ ) in the lower, albeit not the lowermost, part of the Upper Tithonian Crassicollaria Zone (Fig. 18A). The value $1.79 \%$ for sample MG-116 terminates the $\delta^{13} \mathrm{C}$ curve for the Upper Jurassic limestones of the Mały Giewont area, still within the Crassicollaria Zone. Samples MG-119 and MG-120, of Barremian-Aptian age (Wysoka Turnia Limestone Formation), reveal a notable increase of $\delta^{13} \mathrm{C}$ values to $1.99-2.35 \%$.

\section{DISCUSSION}

REMARKS ON THE STRATIGRAPHY OF THE RAPTAWICKA TURNIA LIMESTONE FORMATION

The thickness of the RTL Fm was estimated to be $100 \mathrm{~m}$ in the Mały Giewont area (Lefeld, 1985 in Lefeld et al., 1985: p. 25-34). However, the Callovian-Tithonian (pars) limestones in the section B (Fig. 3) are $99 \mathrm{~m}$ thick. Therefore, the thickness of the whole formation (Callovian-Hauterivian) must be be greater than the reported $100 \mathrm{~m}$ value. Indeed, the Upper Tithonian limestones (Crassicollaria Zone), exposed sporadically in section $\mathrm{A}$, are $\sim 7 \mathrm{~m}$ thick, and - according to Lefeld (1968: fig. 10) - the Berriasian-Hauterivian limestones are $\sim 30$ $\mathrm{m}$ thick. Nevertheless, at present the topmost Tithonian and Berriasian-Hauterivian limestones are not exposed and could not be studied in the sections A and B (Fig. 1C). In section A (Fig. 2), the gap between the Upper Tithonian strata of the RTL Fm and the Barremian-Aptian limestones of the Wysoka Turnia Limestone Formation seems to correspond to lime- stones $\sim 10 \mathrm{~m}$ thick, only. However, in the deep gully called Żleb Kirkora (Fig. 1B), Kotański (1959: pl. XIV) observed 40-60(?) $\mathrm{m}$ of "dark Neocomian" limestones, below the Barremian-Aptian strata.

In the Mały Giewont area, subdivision of the Raptawicka Turnia Limestone Formation into 3 informal members proposed by Lefeld (1968, 1985 in Lefeld et al., 1985: p. 25-34) is partly modified by our data: the olive-grey and brownish-grey limestones appear just in the Upper Kimmeridgian, and the dark limestones occur already in the Tithonian. The boundary between the middle and upper members is shifted downwards ca. $40 \mathrm{~m}$ (between samples MG-86 and MG-87 in section A and between samples G-34-G-37 in section B - Figs. 2 and 3). The middle member - light grey and grey limestones - is 60 to $63.5 \mathrm{~m}$ thick, only, whereas the thickness of the upper member is ca. $38 \mathrm{~m}$ in the Upper Jurassic strata of the formation (section A in Fig. 2). As explained earlier, the uppermost Tithonian and Lower Cretaceous limestones are presently not exposed in the sections studied.

\section{SEDIMENTARY ENVIRONMENT AND PALAEOBATHYMETRIC INTERPRETATIONS}

According to Lefeld and Radwański (1960), the Upper Jurassic limestones of the High-Tatric Succession were deposited in an open, although probably relatively shallow, marine basin. Their pseudo-oolitic limestones (= microoncolitic limestones in this study) were interpreted to be formed below wave base in pelagic conditions, whereas the palaeobathymetry of the basin during deposition of the Saccocoma-bearing limestones remained more or less stable. Later, Lefeld et al. (1986: fig. 4) recognized that the limestones of the RTL Fm (type section), located in the Kościeliska Valley (Fig. 1B), were deposited in the shallower part of the sublittoral zone, below the intertidal environment. This logic can also be applied to the Upper Jurassic limestones of the RTL Fm exposed in the Mały Giewont sections, although these deposits accumulated probably at a relatively shallower depth.

Although not supported by statistically valid data, the common occurrence of the genera Lenticulina and Spirillina in the Kimmeridgian-Tithonian limestones is a characteristic feature of the Upper Jurassic strata studied. According to Schlagintweit and Ebli (1999: text-fig. 3), the maximum of occurrence of Lenticulina in the Plassen Formation in the Northern Calcareous Alps (Upper Kimmeridgian-Lower Valanginian?) was confined to the platform slope (talus facies). However, the Jurassic foraminiferal assemblages containing Lenticulina spp. as the dominant component were found to occur at all bathymetric levels above the CCD (Tyszka, 2001 and publications cited in that paper on page 154). Samson $(1997,2001)$ included Jurassic Spirillinacea in the infralittoral biotope (down to $100 \mathrm{~m}$ ) within the photic zone; also the Ammodiscacea, Ophthalmidiidae (pars) and Textulariaceae belong to this group. The genus Spirillina, although present at all depths, is a component of shallow-water assemblages, usually related to the inner and outer neritic zone (Tyszka, 2001). According to Reolid et al. (2008a, b), the Spirillinidae belong to epifauna indicating the presence of dense bacterial populations. This relation is probably valid also in the case of the Upper Jurassic limestones from the Mały Giewont sections because of widespread occurrence of microoncoids and peloids formed by microbial filaments (A. P. unpub. data). 
The genus Reophax is interpreted as a detritivore and bacterial scavenger (Reolid, 2012, after Nagy, 1992 and Tyszka, 1994). In some Jurassic basins, Reophax was found in the middle and outer shelf environments (Reolid et al., 2008b). Besides Reophax, the genus Textularia was included in the shallow to deep infaunal morphogroup A-8 in the Middle Jurassic of the Pieniny Klippen Belt, southern Poland (Tyszka, 1994). The genus Ammobaculites was assigned to the shallow infaunal morphogroup A-6 (Tyszka, 1994).

Sedimentation rate for the whole RTL Fm was estimated to be 3.6 to 5.2 mm/ka (Vašíček et al., 1994: p. 19). However, in the Mały Giewont section (Fig. 3) sedimentation rate for the Kimmeridgian limestones of this formation could reach up to about $13 \mathrm{~mm} / \mathrm{ka}$ (= $13 \mathrm{~m} / \mathrm{my})$. This is an approximate value as there is no data for the studied sections concerning the exact position of the Oxfordian/Kimmeridgian boundary at the base of the M26 magnetozone proposed by Ogg et al. (2012). In any case, it seems that the estimated sedimentation rate for the Kimmeridgian limestones exceeded the value calculated for the (partly) coeval Jasenina Formation of the Lower Sub-Tatric (Križna) Succession (6.6 to 7 mm/ka after Vašíček et al., 1994: p. 20; 3 to $7 \mathrm{~m} / \mathrm{my}$, after Grabowski and Pszczółkowski 2006; and $3.7 \mathrm{~m} / \mathrm{My}$, after Jach et al., 2012). A relatively higher sedimentation rate of the carbonate deposits was probably an advantageous factor for the genera Spirillina, Lenticulina and Reophax, as reported earlier from the Oxfordian of the Prebetic Zone in the southern Spain (Reolid et al., 2008b).

In the lower and middle parts of the Upper Kimmeridgian, biooncomicrosparites and biomicrites are the dominant types of limestones. The Bositra-Saccocomidae microfacies with ammonites may be interpreted in terms of a transgressive episode. The uppermost Kimmeridgian limestones consist mainly of biomicrites, locally pseudonodular, also indicating a relatively high sea level. Such an interpretation is supported by the presence of sparse calcareous nannoplankton in the peloids and the micritic matrix.

The above-mentioned limestone types are also dominant in the Lower Tithonian, although oncobiosparitic variety locally also occur. The dark limestones of the lower part of the Malmica Zone (Fig. 3), probably correspond to the maximum of the Kimmeridgian-Lower Tithonian transgression (cf. Haq et al., 1987; Reháková, 2000b). As noticed by Hallam (1988: p. 271), the highest sea level occurred "...in the Kimmeridgian and early Tithonian rather than the Oxfordian...". In the Chitinoidella Zone, the oncosparitic beds begin to be common. In section A (Fig. 2), the pseudonodular limestones occur in the uppermost Kimmeridgian strata (upper part of the Moluccana Zone and the Borzai Zone); biomicritic lumps or nodules are surrounded by bioclastic matrix. Also in this section, in the Chitinoidella Zone from sample MG-105 upwards - the oncobiomicrosparites are substituted by oncosparitic limestones; diameters of the microoncoids are greater (up to ca. $1 \mathrm{~mm}$ ) than in the underlying strata. These changes indicate shallowing of the High-Tatric swell during the Late Tithonian. This local shallowing trend is concordant with the long-term eustatic curve (Haq et al., 1987; Reháková, 2000b; Hallam, 2001).

In summary, palaeobathymetric evolution of the Kimmeridgian-Tithonian deposition in the Mały Giewont sections reveals:

- a transgressive episode at the Early/Late Kimmeridgian boundary interval, perhaps corresponding to the "middle" Kimmeridgian transgressive and highstand event (Haq et al., 1987; Reháková, 2000b);

- a transgression peak during the Early Tithonian (Malmica Zone);
- gradual shallowing of the High-Tatric swell in the Late Tithonian.

At the end of the Jurassic, the carbonate deposits of the studied part of the submarine swell were influenced by increased hydrodynamic activity of waves and currents. Micritic and fine-grained calcareous sediment could have been transported towards the deeper areas of the Late Tithonian sea. However, the larger microoncoids $(0.5-1.0 \mathrm{~mm}$ in diameter) remained in the place of their formation (?) or were not farther displaced to the deep-water basins. Evidently, the bottom calcareous sediments were still located below the (fair-weather?) wave base. The microbial concentric coatings of the microoncoids are usually symmetrical or ellipsoidal (Fig. 13C), which is concordant with "some regular degree of turning" (Wright in Tucker et al., 1990: p. 10). This links their origin rather with relatively elevated turbulence in the Late Tithonian sea than with the activity of burrowers.

\section{CORRELATION TRENDS} BETWEEN $\delta^{13} \mathrm{C}$ AND $\delta^{18}$ O DATA

Two correlation trends are clearly visible in the $\delta^{13} \mathrm{C}$ vs. $\delta^{18} \mathrm{O}$ diagram (Fig. 18B). Both trends are of stratigraphical significance. The first trend is discernible between samples MG-56 and MG-82. The $\delta^{13} \mathrm{C}$ values reveal only minor variations (between 2.60 and $2.35 \%$ ), while $\delta^{18} \mathrm{O}$ significantly fluctuates between -3.90 and $-1.21 \%$. Within the second trend (samples MG-84 to MG-116) an apparently positive correlation is observed between both isotopic ratios. The $\delta^{13} \mathrm{C}$ values fall from $2.2-2.3 \%$ to $1.6-1.4 \%$ and $\delta^{18} \mathrm{O}$ decrease from -1.5 to $-3.6 \%$. Such a positive correlation might be evidence of diagenetic alteration of the isotope record (e.g., Weissert and Bréhéret, 1991; Colombié et al., 2011). However, the carbon isotope curve from Mały Giewont in the entire Lower Kimmeridgian-Lower Tithonian interval correlates quite well with other reference sections from the Carpathians (see chapter below). Moreover, the boundary between both correlation trends (samples MG-82 and MG-84) falls just below the boundary of the middle and upper members of the RTL Fm. This corresponds to horizon b with Taramelliceras (see Fig. 3) and correlates with the onset of the Saccocoma-Globochaete microfacies. Therefore the carbon isotope record is interpreted as primary, reflecting important palaeoenvironmental changes in the Western Carpathian area.

CORRELATION OF THE $\delta^{13} \mathrm{C}$ CURVE FROM

THE MAŁY GIEWONT SECTION WITH ISOTOPIC RECORDS FROM OTHER CARPATHIAN SECTIONS

The $\delta^{13} \mathrm{C}$ curve constructed from the samples collected in section A of the Mały Giewont area (Fig. 19) can be compared with the isotopic records from coeval sections studied in Poland (Jach et al., 2014) and Slovakia (Michalík et al., 2009) which are calibrated with calcareous dinocysts and calpionellids. The Długa Valley section from the Western Tatra Mountains comprises three Upper Jurassic formations belonging to the Lower Subtatric (or Fatric) Succession (Jach et al., 2014). The Czajakowa Radiolarite Formation (upper part) is Early Kimmeridgian to earliest Late Kimmeridgian in age. The Czorsztyn Limestone and Jasenina formations consist of Upper Kimmeridgian-Lower Tithonian pelagic limestones (Jach et al., 2012, 2014: fig. 3). In general, the compared $\delta^{13} \mathrm{C}$ 
curves from Mały Giewont and the Długa Valley might be divided in three sectors (Fig. 19).

Sector I comprises a relatively stable, slightly decreasing trend of $\delta^{13} \mathrm{C}$ within the acme Parvula and Moluccana Zones in the Kimmeridgian. The values decrease slightly from 2.60 to $2.36 \%$ in the Mały Giewont section. In the Długa Valley section, this trend is also observed; however, the $\delta^{13} \mathrm{C}$ are lower, falling from ca. $2.2 \%$ in the lower part of the Moluccana Zone to $2-1.8 \%$ in the upper part of this zone. A positive excursion in the upper part of the Upper Kimmeridgian Moluccana Zone (sample MG-87), which terminates sector I, might correspond to sample Dsr292 (Jach et al., 2014: fig. 3). The "Late Kimmeridgian (Moluccana Zone) positive $\delta^{13} \mathrm{C}$ shift" of Jach et al. (2014) should be correlated then, with our samples MG-79 to 82. In that case, the upper part of the middle member of the RTL Fm in the Mały Giewont section must be an equivalent of the the upper part of the Czajakowa Radiolarite Formation (red radiolarites) and Czorsztyn Formation (and perhaps the lowermost part of the Jasenina Formation).

Sector II of the $\delta^{13} \mathrm{C}$ curves from the Mały Giewont and Długa Valley sections represents a remarkable decreasing trend which continues from the uppermost part of Moluccana Zone, through the Borzai Zone and Tithonica - acme Pulla Zone up to the base of the Lower Tithonian Malmica Zone. The $\delta^{13} \mathrm{C}$ values fall from 2.4 to $1.7 \%$ in the Mały Giewont section and from 2.1 to $1.3 \%$ in the Długa Valley section. The trend terminates with a spectacular negative excursion $(-0.37 \%$ for sample MG-98 in the Mały Giewont section) in the lower part of the Lower Tithonian Malmica Zone. The trend corresponds to the lower part of the upper member of the RTL Fm and the lowermost part of the Jasenina Formation.

Sector III of $\delta^{13} \mathrm{C}$ curves from both sections represents again a relatively stable trend within the Malmica Zone. The $\delta^{13} \mathrm{C}$ values fluctuate around $1.8-1.5 \%$ in the Mały Giewont section and around $1.5-1.2 \%$ in the Długa Valley section, with some subordinate minima and maxima. This trend correlates with the middle part of the upper member of the RTL Fm and the corresponding part of the Jasenina Formation.

The three sectors in the Upper Kimmeridgian-Lower Tithonian interval of the $\delta^{13} \mathrm{C}$ curve might be identified also in the Hlboča section (Grabowski et al., 2010). Biostratigraphic correlation of the sectors fits quite well to the Mały Giewont and Długa Valley sections (Fig. 19): sector I - in the upper part of the Parvula and in the Moluccana Zone, sector II in the Pulla Zone and sector III in the Malmica Zone. The latter might be tentatively distinguished also in the Malmica Zone of the Brodno section (Michalík et al., 2009). The weak positive excursion in the lower interval of the Crassicollaria Zone (Fig. 19) may also be found in the Brodno section. The value $1.79 \%$ for sample MG-116 indicates a diminishing trend in the topmost part of the Mały Giewont section. This is compatible with the rather low stratigraphical position of samples MG-113 and MG-116 within the Crassicollaria Zone, probably below the interval of rising $\delta^{13} \mathrm{C}$ values detected in the Brodno section (Michalík et al., 2009).

The decreasing trend of $\delta^{13} \mathrm{C}$ within the KimmeridgianTithonian is a well-known phenomenon (e.g., Cecca et al., 2001; Padden et al., 2002; Weissert and Erba, 2004; Jach et al., 2014; Arabas, 2016; Price et al., 2016). The overall similarity of the $\delta^{13} \mathrm{C}$ decreasing values recorded in the Kimmeridgian-lowermost Tithonian interval of the Mały Giewont area (this study) and the Długa Valley (Jach et al., 2014) sections indicates that the generally shallow-water limestones of the RTL
Fm accumulated below the zone influenced by changes in the composition of marine water caused, for instance, by intense rainfall. Therefore, the depocentre of these limestones located at the top of the passive Tatric Ridge was freely connected with the nearby deep-water basins (such as the Zliechov Basin Michalík, 2007).

\section{CONCLUSIONS}

1. Eight microfossil biozones are distinguished in the Upper Jurassic limestones of the Mały Giewont area (RTL Fm, Western Tatra Mountains): acme Fibrata, acme Parvula, Moluccana, Borzai, Tithonica-acme Pulla(?), Malmica, Chitinoidella and Crassicollaria (pars). The Kimmeridgian/Tithonian boundary is indicated at the top of the Borzai Zone $76 \mathrm{~m}$ above the base of the RTL Fm.

2. The planktonic and benthic foraminifers occur in the Upper Jurassic deposits of the RTL Formation. The genera Lenticulina Lamarck and Spirillina Ehrenberg are common in the Kimmeridgian and Tithonian limestones.

3. The microfossil stratigraphy suggests a late Early Kimmeridgian age (acme Parvula Zone) of the ammonites described by Passendorfer (1928). The taxon Taramelliceras ex gr. compsum found $14 \mathrm{~m}$ above those ammonites is Late Kimmeridgian in age.

4. Seven microfacies types (MF) are identified in the Upper Jurassic limestones of the Mały Giewont area. The Bositra-Saccocomidae MF occurs across the Lower-Upper Kimmeridgian boundary and corresponds to the microfacies $\mathrm{MF}_{\|}$of the Ardèche area in France (Dromart and Atrops, 1988).

5. The isotopic curves $\delta^{18} \mathrm{O}$ and $\delta^{13} \mathrm{C}$ registered from the Kimmeridgian and Tithonian bulk limestone samples (Mały Giewont area, section A) can be compared with the isotopic records from coeval sections studied in Poland (Jach et al., 2014) and Slovakia (Michalík et al., 2009). The overall similarity of the $\delta^{13} \mathrm{C}$ decreasing values recorded in the Kimmeridgian-lowermost Tithonian interval of Mały Giewont (this study) and Długa Valley (Jach et al., 2014) sections indicates that the generally shallow-water limestones of the RTL Fm accumulated below the zone influenced by changes in the composition of marine water caused, for instance, by intense rainfall.

6 . The palaeobathymetric evolution of the Kimmeridgian-Tithonian deposition recorded in the Mały Giewont sections reveals: a transgressive episode at the Early/Late Kimmeridgian boundary interval, a transgression peak during the Early Tithonian (Malmica Zone) and gradual shallowing of the High-Tatric swell in the Late Tithonian.

Acknowledgements. The investigations were financially supported by the project DEC-2011/03B/ST10/05256 of the National Science Centre, Poland. A. P. thanks Dr. F. Olóriz Sáez (Universidad de Granada, Spain) for identification of the ammonite Taramelliceras ex gr. compsum (Oppel) and Prof. $J$. Lefeld for information about the location of the fauna found by Passendorfer (1928). We are grateful to Ing. T. Sztyrak for technical assistance during the fieldwork and thin section preparation. J. Grabowski thanks A. Staniszewska, M. Sc., for indicating the exact location of the Mały Giewont section during an excursion in summer 2011. The remarks of the journal's reviewers: R. Jach, P. Łuczyński, J. Michalík and D. Reháková are greatly appreciated. 


\section{REFERENCES}

Andelković, M.Ž., 1966. Die Ammoniten aus den Schichten mit Aspidoceras Acanthicum des Gebirges Stara Planina in Ostserbien, Jugoslavien (in Serbian with German summary). Paleontologia Jugoslavica, 6: 5-136.

Arabas, A., 2016. Middle-Upper Jurassic stable isotope records and seawater temperature variations: new palaeoclimate data from marine carbonate and belemnite rostra (Pieniny Klippen Belt, Carpathians). Palaeogeography, Palaeoclimatology, Palaeoecology, 446: 284-294.

Baudouin, C., Boselli, P., Bert, D., 2011. The Oppeliidae of the Acanthicum Zone (Upper Kimmeridgian) from Mount Crussol (Ardèche, France): ontogeny, variability and dimorphism of the genera Taramelliceras and Streblites (Ammonoidea). Revue de Paléobiologie, 30: 619-684.

Benzaggagh, M., Atrops, F., 1997. Stratigraphie et association de faune d'ammonites des zones du Kimméridgien, Tithonien et Berriasien basal dans le Prérif interne (Rif, Maroc). Newsletters on Stratigraphy, 35: 127-163.

Benzaggagh, M., Homberg, C., Schnyder, J., Ben Abdesselam-Mahdaoui, S., 2015. Description et biozonation des sections de crinoïdes saccocomidés du Jurassique supérieur (Oxfordien-Tithonien) du domaine téthysien occidental. Annales de Paléontologie, 101: 95-117.

Berckhemer, F., Hölder, H., 1959. Ammoniten aus dem Oberen Weißen Jura-Süddeutschlands. Geologisches Jahrbuch, 35 $1-135$.

Borowska, U., 2015. Stratigraphy of the Lower Tithonian-Lower Aptian limestones of the Niedźwiedź crag from the High-Tatric allochthon, Polish Western Tatra Mountains (in Polish with English summary). Przegląd Geologiczny, 63: 164-171.

Borza, K., 1969. Die Mikrofazies und Mikrofossilien des Oberjuras und der Unterkreide der Klippenzone der Westkarpaten. Vydav. Slov. Akad. Vied, Bratislava, 5-131.

Borza, K., 1984. The Upper Jurassic-Lower Cretaceous parabiostratigraphic scale on the basis of Tintinninae, Cadosinidae, Stomiosphaeridae, Calcisphaerulidae and other micro-fossils from the West Carpathians. Geologicky Zbornik (Geologica Carpathica), 35: 539-550.

BouDagher-Fadel, M.K., Banner, F.T., Whittaker, J.E., with a contribution from M. D. Simmons, 1997. The Early Evolutionary History of Planktonic Foraminifera. British Micropalaeontological Society Public Series. Chapman and Hall, London.

Bralower, T.J., Monechi, S., Thierstein, H.R., 1989. Calcareous nannofossil zonation of the Jurassic-Cretaceous boundary interval and correlation with the geomagnetic polarity scale. Marine Micropaleontology, 14: 153-235.

Casellato, C.E., 2010. Calcareous nannofossil biostratigraphy of Upper Callovian-Lower Berriasian successions from the Southern Alps, North Italy. Rivista Italiana di Paleontologia e Stratigrafia, 116: 357-404.

Cecca, F., Cresta, S., Pallini, G., Santantonio, M., 1990. II Giurassico di Monte Nerone (Appennino marchigiano, Italia Centrale): biostratigrafia, ed evoluzione paleogeografica. In: Fossili, Evoluzione, Ambiente (Atti del secondo convegno internazionale, Pergola 25-30 octobre 1987) (eds. G. Pallini, F. Cecca, S. Cresta and M. Santantonio): 63-139. Comitato Centenario Raffaele Piccinini.

Cecca, F., Savary, B., Bartolini, A., Remane, J., Cordey, F., 2001. The Middle Jurassic-Lower Cretaceous Rosso Ammonitico succession of Monte Inici (Trapanese domain, western Sicily): sedimentology, biostratigraphy and isotope stratigraphy. Bulletin de la Société Géologique de la France, 172: 647-660.

Checa Gonzalez, A., 1985. Los aspidoceratiformes en Europa (Ammonitina, fam. Aspidoceratidae: subfamilias Aspidoceratinae y Physodoceratinae). Ph.D. thesis, Universidad de Granada.
Colombié, C., Lécuyer, C., Strasser, A., 2011. Carbon- and oxygen-isotope records of palaeoenvironmental and carbonate production changes in shallow-marine carbonates (Kimmeridgian, Swiss Jura). Geological Magazine, 148: 133-153.

Dromart, G., Atrops, F., 1988. Valeur stratigraphique des biomicrofaciès pélagiques dans le Jurassique supérieur de la Téthys occidentale. Compte Rendus de l'Académie des Sciences. Paris, 306, Série II: 1365-1371.

Folk, R. 1959. Practical petrographic classification of limestones. AAPG Bulletin, 43: 1-38.

Fontannes., F., 1879. Description des Ammonites des Calcaires du Cháteau de Crüssol (Ardéche). Travaux de l'Université Lyon.

Főzy, I., Janssen, N.M.M., Price, G.D., 2011. High-resolution ammonite, belemnite and stable isotope record from the most complete Upper Jurassic section of the Bakony Mts (Transdanubian Range, Hungary). Geologica Carpathica, 62: 413-433.

Grabowski, J., Pszczółkowski, A., 2006. Magneto- and biostratigraphy of the Tithonian-Berriasian pelagic sediments in the Tatra Mountains (central Western Carpathians, Poland): sedimentary and rock magnetic changes at the Jurassic/Cretaceous boundary. Cretaceous Research, 27: 398-417.

Grabowski, J., Michalík, J., Pszczółkowski, A., Lintnerová, O., 2010. Magneto- and isotope stratigraphy around the Jurassic/Cretaceous boundary in the Vysoká Unit (Malé Karpaty Mountains, Slovakia): correlations and tectonic implications. Geologica Carpathica, 61: 309-326.

Grigore, D., 2011. Kimmeridgian - Lower Tithonian ammonite assemblages from Ghilcoş-Hăghimaş Massif (Eastern Carpathians, Romania). Acta Palaeontologica Romaniae, 7: 177-189.

Hallam, A., 1988. A reevaluation of Jurassic eustasy in the light of new data and the revised Exxon curve. SEPM Special Publication, 42: 261-273.

Hallam, A., 2001. A review of the broad pattern of Jurassic sea-level changes and their possible causes in the light of current knowledge. Palaeogeography, Palaeoclimatology, Palaeoecology, 167: 23-37.

Hantzpergues, P., Atrops, F., Enay, R., 1997. Zonation du Jurassique français par les Ammonites, Kimméridgien. Bulletin du Centre de Recherches Elf Exploration-Production, Pau, 17: 87-96.

Haq, B.U., Hardenbol, J., Vail, P.R., 1987. Chronology of fluctuating sea levels since the Triassic. Science, 235: 1156-1167.

Hart, M.B., Hudson, W., Smart C.W., Tyszka, J., 2012. A reassessment of 'Globigerina bathoniana' Pazdrowa, 1969 and the palaeoceanographic significance of Jurassic planktic foraminifera from southern Poland. Journal of Micropalaeontology, 31: 97-109.

Hölder, H., Ziegler, B., 1959. Stratigraphische und faunistische Beziehungen im Weißen Jura (Kimeridgien) zwischen Süddeutschland und Ardèche. Neues Jahrbuch für Geologie und Paläontologie Abhandlungen, 108: 150-214.

Ivanova, D., Keupp, H., 1999. Calcareous dinoflagellate cysts from the Late Jurassic and Early Cretaceous of the Western Forebalkan, Bulgaria. Berliner Geowissenschaftliche Abhandlungen, 30: 3-31.

Jach, R., Reháková, D., Uchman, A., 2012. Biostratigraphy and palaeoenvironment of the Kimmeridgian-Lower Tithonian pelagic deposits of the Krížna nappe, Lejowa Valley, Tatra Mts. (southern Poland). Geological Quarterly, 56 (4): 773-788.

Jach, R., Djerić, N., Goričan, Š., Reháková, D., 2014. Integrated stratigraphy of the Middle-Upper Jurassic of the Križna Nappe, Tatra Mountains. Annales Societatis Geologorum Poloniae, 84: 1-33.

Kotański, Z., 1959. Stratigraphical sections of the High-Tatric series in the Polish Tatra Mountains (in Polish with English summary). Biuletyn Instytutu Geologicznego, 139: 7-160. 
Kotański, Z., Radwański, A., 1960. Communiqué concerning the occurrence of Lombardia microfacies in the High-Tatra Malm (in Polish). Przegląd Geologiczny, 9: 477-479.

Keupp, H., 1987. Die kalkigen Dinoflagellaten-Zysten des Mittelalb bis Unter-cenoman von Escalles/Boulonnais (N-Frankreich). Facies, 16: 37-88.

Krajewski, M., Olszewska, B., 2007. Foraminifera from the Late Jurassic and Early Cretaceous carbonate platform facies of the southern part of the Crimea Mountains, southern Ukraine. Annales Societatis Geologorum Poloniae, 77: 291-311.

Lefeld, J., 1968. Stratigraphy and palaeogeography of the High-Tatric Lower Cretaceous in the Tatra Mountains (in Polish with English summary). Studia Geologica Polonica, 24: 1-115.

Lefeld, J., Radwański, A., 1960. Les Crinoides planctoniques Saccocoma Agassiz dans le Malm et le Néocomien haut tarique des Tatras Polonaises (in Polish with French summary). Acta Geologica Polonica, 10: 593-614.

Lefeld, J. ed., Gaździcki, A., Iwanow, A., Krajewski, K., Wójcik K., 1985. Jurassic and Cretaceous lithostratigraphic units of the Tatra Mountains. Studia Geologica Polonica, 84: 1-92.

Lefeld, J., Sapunov, I., Tchoumatchenco, P., Bakalova, D., Dodekova, L., 1986. Upper Jurassic-lowermost Cretaceous sequences in the Inner Carpathians (Poland) and in the Balkanids (Bulgaria) - a comparison. Geologica Balcanica, 16: 87-97.

Michalík, J., 2007. Sedimentary rock record and microfacies indicators of the latest Triassic to mid-Cretaceous tensional development of the Zliechov Basin (Central Western Carpathians) Geologica Carpathica, 58: 443-453.

Michalík, J., Reháková, D., Halásová, E., Lintnerová, O., 2009. The Brodno section - a potential regional stratotype of the Jurassic/Cretaceous boundary (Western Carpathians). Geologica Carpathica, 60: 213-232.

Mišík, M., 1998. Stratigraphical horizons and facies with calcareous oncoids, microoncoids and pisoids in the Western Carpathians (in Slovak with English summary). Mineralia Slovaca, 30 195-216.

Nagy, J., 1992. Environmental significance of foraminiferal morphogroups in Jurassic North Sea deltas. Palaeogeography, Palaeoecology, Palaeoclimatology, 95: 111-134.

Nowak, W., 1968. Stomiospherids of the Cieszyn Beds (Kimmeridgian-Hauterivian) in the Polish Cieszyn Silesia and their stratigraphical value (in Polish with English summary). Rocznik Polskiego Towarzystwa Geologicznego, 38: 275-334.

Ogg, J.G., Hinnov, L.A., Huang, C., 2012. Chapter 26 - Jurassic. In: The Geologic Time Scale 2012 (eds. F.M. Gradstein, J.G. Ogg, M.D. Schmitz and M.G. Ogg): 731-791

Ohmert, W., Zeiss, A., 1980. Ammoniten aus den Hangenden Bankkalken (Unter-Tithon) der Schwäbischen Alb (Südwestdeutschland). Abhandlungen des Geologischen Landesamtes Baden-Württemberg, 9: 5-50.

Olóriz Sáez, F., 1978. Kimmeridgiense-Tithonico Inferior en el sector central de las Cordilleras Beticas (Zona Subbetica). Paleontología. Bioestratigrafia. Tesis doctorales de la Universidad de Granada: 184

Olszewska, B., 2010. Microfossils of the Upper Jurassic-Lower Cretaceous formations of the Lublin Upland (SE Poland) based on thin section studies. Polish Geological Institute Special Papers, 26: 1-56.

Olszewska, B., Matyszkiewicz, J., Król, K., Krajewski, M., 2012. Correlation of the Upper Jurassic-Cretaceous epicontinental sediments in southern Poland and southwestern Ukraine based on thin sections. Biuletyn Państwowego Instytutu Geologicznego, 453: 29-80.

Padden, M., Weissert, H., Hanspeter, F., 2002. Late Jurassic lithological evolution and carbon isotope stratigraphy of the western Tethys. Eclogae Geologicae Helvetiae, 95: 333-346.

Passendorfer, E., 1928. Le Kimeridgien dans la Tatra (in Polish with French summary). Sprawozdania Państwowego Instytutu Geologicznego, 4: 491-499.
Passendorfer, E., 1951. Jura Tatr (in Polish). In: Regionalna geologia Polski, 1 - Karpaty (praca zbiorowa); (1) - Stratygrafia (ed. M. Książkiewicz): 49-57. Polskie Towarzystwo Geologiczne, Kraków.

Pavia, G., Benetti, A., Minetti, C., 1987. II Rosso Ammonitico dei Monti Lessini Veronesi (Italia NE). Faune ad Ammoniti e discontinuità stratigrafiche nel Kimmeridgiano inferiore. Bolletino della Società Paleontologica Italiana, 26: 63-92.

Plašienka, D., 1995. Passive and active margin history of the northern Tatricum (Western Carpathians, Slovakia). Geologische Rundschau, 84: 748-760.

Price, G.D., Fözy, I., Pálfy, J., 2016. Carbon cycle history through the Jurassic-Cretaceous boundary: a new global $\delta^{13} \mathrm{C}$ stack. Palaeogeography, Palaeoclimatology, Palaeoecology, 451: 46-61.

Pszczółkowski, A., 2009. The Tithonian-earliest Berriasian Nannoconus zones in selected sections of the Pieniny Klippen Belt and the Western Tatra Mountains (southern Poland). Studia Geologica Polonica, 132: 7-38.

Reháková, D., 2000a. Evolution and distribution of the Late Jurassic and Early Cretaceous calcareous dinoflagellates recorded in the Western Carpathian pelagic carbonate facies. Mineralia Slovaca, 32: 79-88

Reháková, D., 2000b. Calcareous dinoflagellate and calpionellid bioevents versus sea-level fluctuations recorded in the West-Carpathian (Late Jurassic/Early Cretaceous) pelagic environments. Geologica Carpathica, 51: 229-243.

Reháková, D., Matyja, B.A., Wierzbowski, A., Schlögl, J., Krobicki, M., Barski, M., 2011. Stratigraphy and microfacies of the Jurassic and lowermost Cretaceous of the Veliky Kamenets section (Pieniny Klippen Belt, Carpathians, Western Ukraine). Volumina Jurassica, 9: 61-104.

Řehánek, J., Cecca, F., 1993. Calcareous dinoflagellate cysts biostratigraphy in Upper Kimmeridgian-Lower Tithonian pelagic limestones of Marches Apennines (Central Italy). Revue de Micropaléontologie, 36: 143-163.

Reolid, M., Martinez-Ruiz, F., 2012. Comparison of benthic foraminifera and geochemical proxies in shelf deposits from the Upper Jurassic of the Prebetic (southern Spain). Journal of Iberian Geology, 38: 449-465.

Reolid, M., Nagy, J., Rodríguez-Tovar, F.J., Olóriz, F., 2008a Foraminiferal assemblages as palaeoenvironmental bioindicators in Late Jurassic epicontinental platforms: relation with trophic conditions. Acta Palaeontologica Polonica, 53: 705-722.

Reolid, M., Rodríguez-Tovar, F.J., Nagy, J., Olóriz, F., 2008b. Benthic foraminiferal morphogroups of mid to outer shelf environments of the Late Jurassic (Prebetic Zone, Southern Spain): characterization of biofacies and environmental significance. Palaeogeography, Palaeoclimatology, Palaeoecology, 261: 280-299.

Samson, Y., 1997. Utilisation des foraminiféres dans l'estimation des variations bathymétriques des environements de dépôt marins Jurassiques: application au Kimméridgien de l'Ouest-européen. Mémoires Sciences de la Terre, 97-10.

Samson, Y., 2001. Foraminifera and estimation of bathymetric variations: example in the Kimmeridgian of Le Havre area (Seine-Maritime, Normandy, France) (in French with English summary). Revue de Micropaléontologie, 44: 59-91.

Sarti, C., 1985. Biostratigraphie et faune à ammonites du Jurassique superieur de la plate-forme Atesine (Formation du Rosso Ammonitico Veronais). Revue de Paléobiologie, 4: 321-330.

Sarti, C., 1986. Fauna e biostratigrafia del Rosso Ammonitico del Trentino centrale (Kimmeridgiano-Titoniano). Bollettino della Società Paleontologica Italiana, 23: 473-514

Sarti, C., 1990. Dimorfismo nella specie Sowerbyceras loryi (Mun. Chlm.) del Kimmeridgiano. In: Atti II Conv. Int. F.E.A. Pergola 25-30 ottobre 1987 - "Fossili, Evoluzione, Ambiente" (eds. G. Pallini, F. Cecca, S. Cresta and M. Santantonio): 427-439. 
Sarti, C., 1993. II Kimmeridgiano delle Prealpi Veneto-Trentine: fauna e biostratigrafia. Memorie del Museo Civico di Storia Naturale di Verona (II Serie). Sezione Scienzedella Terra, 5: 9-145.

Schlagintweit, F., Ebli, O., 1999. New results on microfacies, biostratigraphy and sedimentology of Late Jurassic-Early Cretaceous platform carbonates of the Northern Calcareous Alps, Part I: Tressenstein Limestone, Plassen Formation. Abhandlungen der Geologischen Bundesanstalt, 56: 379-418.

Tucker, M.E., Wright, V.P., Dickson, J.A.D., 1990. Carbonate Sedimentology. Blackwell Science.

Tyszka, J., 1994. Response of Middle Jurassic benthic foraminiferal morphogroups to dysoxic/anoxic conditions in the Pieniny Klippen Basin, Polish Carpathians. Palaeogeography, Palaeoecology, Palaeoclimatology, 110: 55-81.
Tyszka, J., 2001. Microfossil assemblages as bathymetric indicators of the Toarcian/Aalenian "Fleckenmergel"-facies in the Carpathian Pieniny Klippen Belt. Geologica Carpathica, 53: 147-158.

Vašíček, Z., Michalík, J., Reháková, D., 1994. Early Cretaceous stratigraphy, palaeogeography and life in Western Carpathians. Beringeria, 10: 3-169.

Weissert, H., Bréhéret, J-G., 1991. A carbonate carbon-isotope record from Aptian-Albian sediments of the Vocontian trough (SE France). Bulletin de la Societe Géologique de la France, 162: 1133-1140.

Weissert, H., Erba, E., 2004. Volcanism, $\mathrm{CO}_{2}$ and palaeoclimate: a Late Jurassic-Early Cretaceous carbon and oxygen isotope record. Journal of the Geological Society, 161: 695-702. 